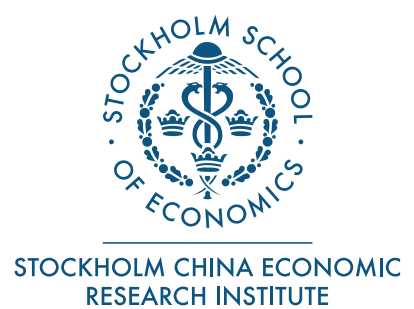

\title{
Can Mutual Funds Pick Stocks in China? Evidence from the IPO Market
}

\author{
Xunan Feng \\ Southwestern University of Finance and Economics \\ Anders C. Johansson \\ Stockholm School of Economics
}

Stockholm School of Economics Asia Working Paper

No. 32

September 2014 


\title{
Can Mutual Funds Pick Stocks in China? Evidence from the IPO Market
}

\author{
Xunan Feng \\ Southwestern University of Finance and Economics \\ Anders C. Johansson ${ }^{1}$ \\ Stockholm School of Economics
}

September 2014

${ }^{1}$ Corresponding author, Stockholm School of Economics, P.O. Box 6501, SE-113 83 Stockholm, Sweden. Email: anders.johansson@hhs.se. Feng acknowledges financial support from the National Natural Science Foundation of China (71302049). 


\title{
Can Mutual Funds Pick Stocks in China? Evidence from the IPO Market
}

\begin{abstract}
This study examines the stock-picking ability of mutual funds in China using evidence from the IPO market. We hypothesize that the decision to invest in the IPO market contains positive information about a fund's underlying expectation of newly listed firms' future prospects. Using residuals from a model on the determinants of mutual funds purchases in the IPO market as proxy for consensus expectations, we find that IPO firms with high residual funds have significantly better stock returns and operating performance than those with low residual funds. In other words, residual funds can predict IPO future performance. This result is also robust to different specifications and alternative explanations such as mutual fund preferences or monitoring effects.
\end{abstract}

JEL Classification: G15; G23; G30; L25

Keywords: Mutual funds; Stock picking ability; IPO; China 


\section{Introduction}

Whether mutual funds can collect and analyze information, and thereby select outperforming stocks and earn risk-adjusted excess returns, is an important question for the financial industry as well as for academia due to its practical implications for investors and its theoretical implications for market efficiency. Although much research (Jensen, 1968; Gruber, 1996; Elton et al, 1993; Carhart, 1997 et al) conclude that mutual funds' performance on average is inferior to a set of passive benchmarks ${ }^{2}$, large amounts of money still flow into actively managed funds and the fund industry continues to grow rapidly.

Unlike earlier studies on stock-picking ability that use a fund performance measure ${ }^{3}$, this paper uses an event study methodology to investigate the issue. The new issue market is characterized by a high degree of uncertainty and information asymmetry and hence provides a useful setting to examine funds' stock-picking abilities. IPOs tend to be risky because firms that go public are often smaller and younger, with little financial records, going through a transitory growth period, characterized by a lack of transparency and uncertainty regarding future prospects, which makes them difficult to analyze and value. In addition, many IPO firms fail or

\footnotetext{
${ }^{2}$ Another strand in this literature argues that at least some mutual funds possess superior stock-picking talents (e.g. Grinblatt and Titman, 1989, 1993; Grinblatt et al., 1995; Wermers, 1997; Wermers, 2000; Kacperczyk and Seru,2007; Kacperczyk et al., 2008; Fama and French, 2010). For example, Grinblatt and Titman $(1989,1993)$ find that some mutual funds have the ability to choose stocks that outperform benchmarks, even after taking expenses and fees into account.

${ }^{3}$ For example, studies on the so-called "hot hands" phenomenon (e.g. Hendricks, et al., 1993; Goetzmann and Ibbotson, 1994; Malkiel, 1995) address the related issue of whether some funds are performing better than others by discussing the persistence in fund performance.
} 
go bankrupt only a few years after they go public. A natural question is therefore whether mutual funds exhibit special stock selection abilities when facing so many risks. Ordinarily, data limitations make it difficult to analyze this question. Fortunately, we have obtained data for the Chinese stock market that enable this interesting analysis.

Other characteristics in the Chinese IPO market also exacerbate the investment risk for mutual funds. For example, Aharony et al. (2000) argue that "financial packaging”4 (cai wu bao zhuang) is a common phenomenon in China. Moreover, institutional investors, including mutual funds, used to face a three-month lock-up period after an IPO. Thus, although a potentially higher initial return may lure mutual funds into the IPO primary market, information asymmetry and lock-up constraints, combined with the fact that newly listed firms often underperform the market (Ritter, 1991; Loughran and Ritter, 1995) increases the risk associated with investing in the Chinese IPO market. This suggests that only funds with favorable expectations for IPO firms' future performance will invest, which in turn implies that, ceteris paribus, firms with prospects that are deemed favorable will be bought by more funds than firms with prospects that are deemed unfavorable. Thus, if mutual funds on average exhibit stock-picking abilities, the number of mutual funds that invest in new firms in the IPO market contains positive information about funds' true expectations and thereby also about IPO firms’ future performance.

\footnotetext{
${ }^{4}$ The term financial packaging also suggests earnings manipulation or financial fraud. Aharony et al. (2000) discuss this phenomenon among state-controlled firms in China.
} 
Besides the underlying expectations of mutual funds, other factors may also affect the number of funds that invest in IPO firms. For example, the bigger the issue size, the more likely mutual funds are to invest. Because our focus is on the stockpicking ability of mutual funds, and because the true expectations for firms' prospects affect their investments in the primary market, we need to further control for firm and issue characteristics (for example, firm size and underwriter reputation) that affect funds' buying behavior. The residual from this model of initial mutual funds buying in the IPO market, what we call residual funds, is used as a proxy for the underlying expectations of mutual funds as the model residual measures the unexpected factor that affect funds' IPO buying decisions, having taken other known determinants into consideration. If mutual funds on average have strong stock-picking skills, then the IPO firms that are perceived as having a positive future by mutual funds will perform better. That is, ex ante favorable expectations on IPO firms, proxied by high residual funds, should exhibit a corresponding ex post superior performance. Our main hypothesis is that if mutual funds exhibit strong stock-picking abilities, residual funds are positively correlated with the future performance of IPO firms.

This study uses a two-step approach to analyze the stock-picking ability of mutual funds in China. First, we run a standard regression with the number of mutual funds that invest in a new IPO as the dependent variable. Independent variables include typical firm and IPO-specific variables. We then take the residuals from the regression, what we call the residual funds, and use them to categorize the IPOs into three subsamples. To analyze post-IPO performance, we first apply three alternative 
methods to evaluate long-run stock return performance: buy-and-hold abnormal returns (BHARs), Carhart's (1997) four-factor model, and Fama and MacBeth’s (1973) panel regression approach. We find that post-IPO long-run performance is significantly and positively related to residual funds regardless of which of the three methods we use to analyze stock performance. For example, when we calculate the excess returns against a portfolio matched by size and book-to-market value, we find that the BHAR over one year (three years) for IPO firms characterized by high residual funds is $-2.1 \%(12.7 \%)$ compared to $-11.4 \%(-19.4 \%)$ for firms characterized by low residual funds. We then analyze three alternative measures of operating performance: return on assets (ROA), return on sales (ROS), and return on equity (ROE). We find that post-IPO operating performance is also significantly and positively associated with mutual funds' underlying expectations. This result also holds up when we analyze industry-adjusted operating performance. Alternative explanations, such as mutual funds' preference for well-governed IPO firms or their monitoring role, cannot explain these findings. We thus provide empirical evidence that Chinese mutual funds are able to pick outperforming stocks in the primary market.

This study makes important contributions to several strands of literature. First, most studies discuss the stock-picking ability of mutual funds based on stock holding information or net/gross fund returns (Grinblatt and Titman, 1989, 1992; Grinblatt et al., 1995; Wermers, 1997; Daniel et al., 1997; Chen et al., 2000; Wermers, 2000; Kosowski et al., 2006; Kacperczyk and Seru, 2007; Kacperczyk et al., 2008). 
Typically, these studies argue that only a small number of funds possess superior stock picking ability. We instead investigate the stock-picking ability of mutual funds by using an event study approach. A suitable event setting enables us to analyze stock-selection skills from a different angle. Not only does it greatly reduce the concern that fund performance possibly captures luck rather than skills, but it also alleviates Fama's (1970) joint hypothesis problem. When examining fund performance or the performance of the stocks held by mutual funds, most researchers attempt to identify star funds and test the skills of individual funds. Our approach instead focuses on the fund industry's aggregate stock-picking ability as we analyze whether the consensus opinion of the fund industry about an IPO stock can predict future performance. This study therefore complements the existing literature on stock picking abilities of mutual funds.

It should be noted that we are not the first to use a special setting as a framework for studying mutual funds' stock-selection skills. The earning announcement events in Baker et al. (2010) and the corporate mergers setting in Nain and Yao (2013) are related to our study. Similar to their approach, we suggest that stock-picking ability can be derived from trading rather than holding. The main difference from these previous studies is that we analyze the ability of mutual funds to pick stocks from an industry angle, while Baker et al. (2010) focus on average funds and Nain and Yao (2012) analyze individual funds. In addition, our industry approach means that this study also complements those of Grinblatt and Titman (1989), Wermers (1999), and Chen et al (2000), who find that trading by mutual funds 
illustrates certain stock-picking skills. However, our approach differs from theirs in that we can clearly identify mutual funds' trading in the IPO market, while their studies indirectly calculate trades using the change in quarterly holdings. One limitation of using an event study to discuss the stock-picking ability of mutual funds, including ours, Baker et al. (2010), and Nain and Yao (2012), is that it is mainly confined to a particular, well-defined selection skill, not the total abnormal returns earned by mutual funds. However, this approach focuses on the fund's stock selection ability around the specific events, thus offering a useful complement to traditional performance metrics.

Second, our study adds to the literature on IPO long-run underperformance (Ritter, 1991; Loughran, 1993; Levis, 1993; Espenlaub et al., 2000; Hertzel and Lemmon, 2002; Schultz, 2003). IPO underperformance is widely debated because it may indicate an inefficient allocation of resources, investor sentiment or arbitrage opportunities, etc. Our focus is not on whether or not this phenomenon exists or what causes it. Instead, we look at what it is that significantly predicts the difference in post-IPO long-run stock returns. We find that the variable we create, residual funds, significantly affects post-IPO performance of newly listed firms and that the long-run underperformance puzzle only exists for IPOs with low residual funds. This is consistent with our hypothesis that mutual funds exhibit superior stock-picking abilities as IPO firms that are seen in a favorable light by mutual funds perform better in the future.

Third, the study adds to the few existing studies on mutual funds in China. 
Yuan et al. (2008) find that equity ownership by mutual funds is positively related to firm performance and explain this relationship from the perspective of the potential governance role of mutual funds. We, on the other hand, find that it is the stockpicking talent of mutual funds, rather than the monitoring role, that is the main reason behind superior post-IPO stock performance of firms characterized by investments from more mutual funds. The findings in this study therefore suggest that we should be careful when discussing the possible role of mutual funds for listed companies in China.

The rest of the paper proceeds as follows. Section 2 discusses the institutional background. Section 3 presents the data sample, introduces the variables and provides descriptive statistics. Section 4 analyzes the investment decision of mutual funds in the Chinese IPO market. Section 5 presents the empirical results on the relationship between mutual funds' stock selection in the IPO market and post-IPO stock performance, while Section 6 presents the results on mutual funds' IPO firm selection and post-IPO operating performance. Section 7 presents robustness tests to control for alternative explanations of our findings and discusses potential empirical issues. Finally, Section 8 concludes the paper.

\section{Institutional Background}

Over the past three decades, China has transitioned from a command economy towards a market-oriented one. Similarly, the country's administrative governance system for IPOs has also evolved alongside the rapid development of the stock market, 
although it is still under strict control of the government. The initial so-called IPO endorsement system (shen pi zhi) was officially in place from 1993 to 2000. The endorsement system was basically a traditional planning tool, used to design and distribute IPO quotas. As long as a ministry or a local government selected and deemed it to be qualified for an IPO, it was certain that the firm would undergo an IPO sooner or later. ${ }^{5}$

In July 1999, the Securities Law ${ }^{6}$ was enacted. As a result, the IPO approval system (he zhun zhi) was established under the guidelines of the China Securities Regulatory Commission (CSRC). The new system weakened the existing administrative selection process for IPOs while adding to the responsibilities of investment banks, and can therefore be seen as a first step to introduce more marketfriendly measures. In an effort to improve the system further, a new "sponsorship system for offering and listing of securities tentative procedures” 7 entered into effect in February 2004, with the goal of improving the regulation of new issuing activities and promoting sound practices of both issuers and sponsors. The IPO sponsorship system not only emphasizes the sponsor responsibilities of underwriters, but also introduces new methods of pricing an IPO. Before the sponsorship system, the IPO offer price was almost entirely set by the government. Under the sponsorship system, on the other hand, the offer price is primarily set by institutional investors. In practice, the system can be seen as a hybrid offering mechanism, combining book-

\footnotetext{
${ }^{5}$ For a detailed discussion on this, see Pistor and $\mathrm{Xu}$ (2005).

${ }^{6}$ See http://www.reformdata.org/content/19981229/5770.html .

${ }^{7}$ See http://www.gov.cn/gongbao/content/2004/content_62916.htm.
} 
building and fixed-price methods. Book-building helps investment bankers generate, capture, and record investor demand for IPO shares and also supports efficient price discovery (Benveniste and Spindt, 1989; Sherman and Titman, 2002; Ljungqvist and Wilhelm, 2002). In the book-building process, institutional investors play a critical role for pre-market price discovery because they collect the information and analyze the issuer in a professional way, thus revealing both public and private information in a more efficient way.

It should be noted that China only applies part of the book-building approach seen in the U.S. For example, investment bankers in China have no discretion to give certain bidders a greater share allocation than others. This may potentially reduce the incentives for bidders to tell the truth when it comes to real demand in the new issue market. ${ }^{8}$ Book-building in China also has its own characteristics. For example, when investment bankers allocate shares to investors who participate in the book-building process, the shares allocated to such investors are not allowed to exceed $20 \%$ of the total number of shares offered to the public in the primary market if the total number of offered shares is less than 400 million. Similarly, if the number of offered shares is 400 million or more, the shares allocated to such investors are not allowed to exceed

\footnotetext{
${ }^{8}$ For more details on the role of pricing and allocating power on true information revelation, see theoretical studies on book-building, or IPO mechanism design, and more broadly, auctions of divisible goods, as suggested by Dasgputa and Hansen (2007). As it turns out, there is no affirmative conclusion on their respective role in revealing information.
} 
$50 \%$ of the total number of shares offered. Moreover, if the total number of shares purchased at or above the issue price is greater than the total number of shares to be allocated when the book-building price inquiry is completed, the banker must allocate shares on a pro rata basis. The remaining shares not allocated to investors who participate in the price discovery process are offered to the public at a fixed price. This way, investment bankers in China only enjoy the right to price the offer, but have no discretion when it comes to allocating the shares, thus making the IPO offering mechanism in China a hybrid model of the book-building and fixed-price methods. However, it is this special feature that enables us to clearly identify the stock selection ability of mutual funds. Even if similar data sets on mutual funds are publicly disclosed in U.S. or other countries, investment banks typically have full discretion in allocating shares to their preferred customers, which in turn will affect the analysis of mutual fund investments.

During the Third Plenary Session of the 18th Communist Party of China Central Committee ${ }^{9}$ in October 2013, it was decided that the issuance process should be simplified by implementing a registration-based listing system (zhu ce zhi) instead of the current approval-based system. This change would force investors, not regulators, to assess IPO risks. If this reform is carried out, the IPO mechanism will become more market-oriented and similar to those typically used in developed economies.

\footnotetext{
${ }^{9}$ See http://news.xinhuanet.com/house/suzhou/2013-11-12/c_118113773.htm.
} 


\section{Data Sample and Variables}

\subsection{Sample Selection}

The Chinese government decided to develop the mutual fund industry in 2000 (Firth et al., 2010). As a result fund data is available from that year. However, as discussed in the previous section, the laws, rules and regulations surrounding IPOs have changed a number of times since the establishment of the stock market in the early 1990s. To minimize the risk of potential effects of regulatory changes, we focus on the period 2005-2010, during which the sponsorship system was used and no significant regulatory changes were made. ${ }^{10}$ Our sample therefore comprises all initial public offerings with A-shares in China during the period 2005-2010.

The financial and stock price data is from the China Security Market and Accounting Research (CSMAR) database, which offers detailed information on all listed firms in China. Individual funds' IPO allocation data is from Gildata, a database that is provided by Hundsun Technologies. To control the quality of the data, we randomly selected 50 companies for which we went through the "Announcement on Pricing, Offline Issuance Result and Online Lot-winning Rate for Initial Public Offering of A Shares”. This announcement discloses the original data on IPO allocation for each mutual fund. We found no discrepancies in the data and therefore concluded that the data from Gildata is of sufficient quality.

\footnotetext{
${ }^{10}$ The sponsorship system was established in 2004. For a firm to be listed on the stock exchange, it has to be sponsored by a securities company. The sponsor is also required to appoint sponsor representatives to the sponsored firm.
} 
After removing IPOs that were carried out using nonstandard methods ${ }^{11}$, we obtain our final sample, which is presented in Table 1. Panel A presents the year distribution of the IPOs. The number of IPOs per year varied significantly during 2005-2010. One reason behind this variation is that the government imposes occasional formal suspensions of new offerings. For example, IPOs were suspended from 25 May 2005 to 2 June 2006. Similarly, following the onset of the global financial crisis, new IPOs were suspended from 16 September 2008 until 17 June 2009. Taking the suspension period in 2008 and 2009 into account, it is clear that the number of IPOs per year has been on a steady rise. In 2005, a modest 14 new listings took place. During the subsequent years, the number of annual IPOs was at least 65 . Partly a result of the lifting of the previous suspension, the number of IPOs during 2010 was particularly high. A total of 347 IPOs took place that year, corresponding to 47.93\% of the total number of IPOs throughout the sample period. Besides the lifting of the suspension of new offerings in late 2009, an unusual number of listings on the Growth Enterprise Market in Shenzhen took place in 2010. Out of the 347 of the companies that went public that year in China, 117 were listed on the Growth Enterprise Market in Shenzhen. Due to the significant number of companies listed on the Growth Enterprise Market, and due to the fact that the criteria for listed firms

\footnotetext{
${ }^{11}$ The deleted IPOs are: Shanghai International Port Group Co., Ltd. (600018), Weichai Power Co., Ltd. (000338), Aluminum Corporation of China Ltd. (601600), the Pacific Securities Co., Ltd. (601099), Shanghai Electric Group Co., Ltd. (601727), Heilongjiang Transport Development Co., Ltd. (601188), and Jilin Expressway Co., Ltd. (601518).
} 
differ substantially between the Growth Enterprise Market and the main boards ${ }^{12}$, we control for place of listing in the empirical analysis.

Panel B presents the industry distribution of the IPOs during 2005-2010. ${ }^{13}$ The new listings are quite evenly spread out across industries, except for machinery and information technology industries, which contain a large number of IPOs throughout the sample period. To take potential industry-specific characteristics into account, we control for industry effects in the empirical analysis.

[Table 1 about here]

\subsection{Variable Description and Descriptive Statistics}

The focus of this study is on mutual funds' ex ante underlying expectations of IPO firms. As these expectations are unobservable directly, we need to infer them. Before doing so, we discuss the variables that may impact mutual funds' decision to invest in the IPO primary market.

The variables used in the empirical analysis and their descriptive statistics are presented in Table 2. The mean value for each variable is tabulated for the full sample and its corresponding median value is given in parenthesis. Since we are interested in the underlying expectations on IPO by mutual funds, we first need to identify the number of mutual funds that finally buy shares in the primary market for each IPO.

\footnotetext{
${ }^{12}$ For more details on various listing criteria on the different exchanges, see CSRC (2006) and CSRC (2009).

${ }^{13}$ Industry is classified according to the Guidelines for the Industry Classification of Listed Companies by CSRC (2001 Revision).
} 
We call this number Original Funds. In our sample, there is an average of 42 mutual funds that purchase shares in each IPO. The distribution of the number of mutual funds is skewed, with a median value of 33. The smallest value of Original Funds is 1 and the largest 198 (not reported in the table). This means that at least one mutual fund invested in each IPO in our sample.

We then divide the sample into three subsamples based on the number of mutual funds that invest at the time of the IPO. We label them Low, Medium, and High Funds, respectively, corresponding to below 33.33\%, between $33.33 \%$ and $66.67 \%$ and above $66.67 \%$ of Original Funds. As can be seen in Table 2, an average of 10.84, 33.42, and 80.37 funds invested in the Low, Medium, and High Funds samples, respectively. The final column presents the results of tests for the difference in the mean (T-test) and median (Wilcoxon-Mann-Whitney test) of the Low and High Funds samples. The results of the tests show that the difference is significant at the $1 \%$ level.

When we analyze the relationship between mutual fund investment and postIPO performance, we also need to take potential IPO- and firm-specific factors into account. We therefore add a set of variables to the analysis. First, we look at the underwriters of the IPO. Previous research has shown that underwriter reputation is closely related to post-IPO performance (Carter and Manaster, 1990; Carter, Dark and Singh, 1998). In their pioneering study on underwriter reputation, Carter and Manaster (1990) focus on the ranking of underwriters by using tombstone ads that disclose participants in a specified order according to their role in the underwriting of 
IPOs. Carter and Manaster's underwriter ranking system is based on the premise that underwriters carefully guard their names and the order in which their names appear on IPO tombstones. China typically lacks this type of announcements, and we therefore need to measure the underwriter's reputation differently. Having discussed underwriter's reputation with investment bankers in China, we created the variable Reputable Underwriter, which is a dummy variable that equals one if the total amount of IPO share sold or the total number of IPOs the underwriter underwrote during the previous three years is among the top $10 \%$ and zero otherwise. Table 2 shows that $20 \%$ of the total number of IPOs was underwritten by investment banks characterized by strong reputation. For the IPOs in the Low Funds sample, only $16 \%$ were underwritten by investment banks with strong reputation, compared to $25 \%$ for IPOs in the High Funds sample. The tests for differences in the mean and median show that the proportion of reputable underwriters for IPOs was significantly higher in the High Funds sample at the 5\% level.

In addition to the importance of underwriter reputation, previous research has shown that the choice of auditor serves as an important signal during the IPO process (Titman and Trueman, 1986; Beatty, 1989; Michaely and Shaw, 1995). Similar to previous research on auditor reputation, we focus on well-known international audit firms, as they are likely to signal a high level of auditing quality. We create the dummy variable Big4, which is equal to one if the auditor of the firm that is going public is one of the big four international accounting firms (Deloitte, Ernst \& Young, KPMG, and PricewaterhouseCoopers) and zero otherwise. During the sample period, 
$7 \%$ of the firms that went public had an auditor that belonged to the big four. Only 3\% of the firms in the Low Funds subsample used such an auditor, while the corresponding ratio was 13\% for the High Funds firms. Again, tests for differences in the mean and median show that firms belonging to the High Funds group used reputable auditors more, and that this difference was significant at the $1 \%$ level.

For completeness, we include a series of measures related to the IPO offer price ${ }^{14}$ First, we include IPO underpricing, measured as the difference between the closing price on the first trading day and the offering price, as underpricing of a public offering can significantly affect long-term post-IPO stock performance. Second, we include IPO value, which we define as the natural logarithm of the offering size. Third, we include the P/E-ratio, measured as the ratio of the offering price to the earnings per share, which in turn is the ratio of the average annual earnings during three years before the IPO to the total number of shares after the IPO. Fourth, the Offer price, measured as the offer price for the IPO firm, is included.

The final IPO-related variable that we include in the empirical analysis is Offer Ratio, which we measure as shares offered in the IPO over total shares. Table 2 shows that the offer ratio is almost identical across the subsamples, with a somewhat but insignificantly smaller ratio for the High Funds firms.

Moving on to the firm-specific variables, we first focus on ownership characteristics. We define Largest Ownership as the percentage ownership in the

\footnotetext{
${ }^{14}$ To address the potential issue of the information in these variables not being fully available before the IPO, we also ran additional tests in which we excluded these variables related to the IPO offer price. The results remained qualitatively the same.
} 
company held by the largest owner. The mean and median size of the holdings of the largest shareholder differs somewhat across the subsample, ranging from 39\% for Medium Funds firms to 52\% for Low Funds firms. However, the difference is not large, and the difference in the mean and median between the Low Funds and High Funds firms is insignificant.

Next, we follow the literature on corporate governance in China (Bai et al, 2004; Wei et al, 2005; Chen et al, 2006) and add a set of governance variables. First, we include Pyramid, a dummy that equals one if the ultimate owner controls the listed firm through at least one firm, and zero otherwise. We include this variable because recent evidence suggests that pyramidal structures are used by the largest shareholder for tunneling and, thus, expropriation of minority shareholders (La Porta et al., 1999; Johnson et al., 2002; Claessens, 2000; Jian and Wong, 2010; Jiang et al., 2010). Looking at Table 2, there is some variation across the different groups, but the difference between Low Funds and High Fund is again insignificant. We then include Non-Duality, a dummy that equals one if the CEO is not the Chairman of the Board and zero otherwise. We add this variable because earlier studies support the view that separating the two increases board independence and improves firm performance (e.g. Rechner and Dalton, 1991; Jensen, 1993, Bai et al., 2004). Here, we find a significant difference between the Low Funds and High Funds samples as High Funds firms are characterized by a higher degree of duality. Independent Directors, measured as the ratio of independent directors to the total number of directors on the board, is also 
included. The difference between Low and High Funds for this variable turns out to be insignificant.

We also take potential differences in ownership into account. First, we add Other institutions, calculated as the ratio of other institutions' shareholders’ aggregate holdings over total shares. We add this variable because these other institutional investors may also play a monitoring role (Gillan et al., 2000; Woidtke, 2002; Chen et al., 2007; Cheng et al., 2010). Here, other institutions refer to VC/PE firms, pension funds, trust funds, insurance companies, and asset management products from brokerage houses. While the ownership ratio for this group of investors is somewhat higher for Low Funds firms, it is not statistically different from that of High Fund firms. Using other definitions, e.g. only including VC/PE firms, does not change the main results. Another potential ownership issue is that of ultimate ownership, i.e. state versus private ownership. Since the beginning of the economic reforms in 1978, China's economy has changed dramatically. In the mid-2000s, the private sector had grown to the extent that it accounted for approximately half of China's total GDP (Tsai, 2007; Feng et al., 2014). Today, there exist both state- and privately controlled firms on the Chinese stock exchanges. To take the differences in ownership into account, we create the dummy variable Private Firm, which is equal to one if the ultimate owner is a person and zero otherwise. Table 2 shows that, even though the Low Funds group includes a higher proportion of firms controlled by private individuals compared to both Medium Funds and High Funds firms, the difference for Low Funds and High Funds firms is not significantly different from zero. 
The remaining firm-specific variables are standard financial measures: Sales Growth is measured as the average ratio of the growth of sales during the three years prior to the IPO; $R O E$ is calculated by taking the average ratio of return on equity during the three years prior to the IPO; Leverage is measured as the average ratio of short- and long-term debt to total assets during the three years prior to the IPO; and Firm Size is defined as the average of the natural logarithm of total assets during the three years prior to the IPO. These financial measures are also adjusted by CSRC industries.

To control for the effect of product market competition, we also include two industry-specific variables. First, we add Industry leader, an indicator that shows whether the firm takes up a leading position in its industry. Here, we define an industry leader as a firm that is ranked in the top $30 \%$ in terms of sales in a specific industry. For this variable, we find a significant difference between the different groups, with the High Funds firm sample having a significantly larger share of industry leaders. Second, we include a measure for market competition: the Herfindahl-Hirschman Index (HHI). We calculate the HHI by using all listed firms' sales from the same industry just before the IPO year. While the competition measure is somewhat higher for High Funds firms, the difference between Low Funds and High Funds firms is not statistically significant.

To control for the general stock market, we similarly define Per 1 Month IPOs as the number of new IPOs during the last month prior to the listing. That is, the higher the number of new IPOs during the previous month, the hotter the IPO market. 
Finally, as mentioned in Section 2.1, the listing location may also impact the interest from mutual funds since larger firms are often listed on the Shanghai Securities Exchange. The IPOs in our sample are listed on the Shanghai Main Board, the Shenzhen Small and Medium Board, or the Shenzhen Growth Enterprise Board. We therefore create two dummies to control for place of listing. The first dummy is equal to one if the listing takes place on the Small- and Medium-Sized Enterprise Board and zero otherwise. Correspondingly, the second dummy variable is equal to one if the listing takes place on the Growth Enterprise Board and zero otherwise. There is no significant difference in the proportion of the firms listed on the Small- and MediumSized Enterprise Board across the different subsamples. When it comes to firms listed on the Growth Enterprise Board, on the other hand, the Low Funds sample has a much higher proportion of listings (25\%) compared to the High Funds sample (11\%) and the difference is statistically significant.

[Table 2 about here]

\section{Mutual Funds' Stock Picking in the IPO Market}

We start the empirical analysis by focusing on the stock picking of mutual funds in the IPO market. Here, we use a methodology that is similar with Hong et al. (2000) and Das et al. (2006). While their main focus is on analyst coverage, we instead analyze mutual fund investments. Hong et al. (2000) argues that analyst 
coverage can be used as a proxy for the rate of information flow, while Das et al. (2006) conjecture that analyst coverage contains information about underlying expectations of a firm's future prospects. In this study, we argue that, by inferring mutual funds' underlying expectations on IPO, we are able to deduce the stockpicking ability of the mutual funds. We believe that the propensity for a mutual fund to invest in an IPO reflects its true expectations about the firm's future stock performance as mutual fund managers are primarily driven by compensation or reputation, which are often tied to the performance of the portfolio they manage. Thus, more mutual funds purchasing an IPO stock indicate more positive opinion on its future prospect from the fund management industry.

In order to find a good proxy to measure the underlying expectations on IPOs by mutual funds, we first need to formulate and run a model on Original Funds, controlling for the known factors that potentially affect the purchasing decision of mutual funds. To reduce the concern that omitted variables may affect our results, we introduce a host of covariates related to their IPO buying decisions, such as IPO-, governance-, firm-related characteristics, and other variables used in previous research. To do this, we apply a standard ordinary least square (OLS) model with the following characteristics: 


$$
\begin{aligned}
\text { Original Funds } & =\alpha+\beta_{1} \text { Reputable Underwriter }+\beta_{2} \text { Big } 4+\beta_{3} \text { IPO Underpricing } \\
& +\beta_{4} \text { IPO Value }+\beta_{5} \text { PE Ratio }+\beta_{6} \text { Offer Price }+\beta_{7} \text { Offer Ratio } \\
& +\beta_{8} \text { Largest Ownership }+\beta_{9} \text { Pyramid }+\beta_{10} \text { NonDuality } \\
& +\beta_{11} \text { Independent Directors }+\beta_{12} \text { Other Institutions } \\
& +\beta_{13} \text { Private Firm }+\beta_{14} \text { Industry Leader }+\beta_{15} \text { Sales Growth } \\
& +\beta_{16} \text { ROE }+\beta_{17} \text { Leverage }+\beta_{18} \text { Firm Size }+\beta_{19} H H I \\
& +\beta_{20} \text { Pre } 1 \text { Month IPOs }+\sum_{i} \text { Listing Board }{ }_{i}+\sum_{j} \text { Year }_{j} \\
& +\sum_{k} \text { Industry } \\
& +\varepsilon
\end{aligned}
$$

in which Original Funds is defined as the number of mutual funds purchasing the IPOs in the primary market. ${ }^{15}$ The other variables are the same as those used in the previous section. Listing Board, Year and Industry dummies are included but not reported for brevity.

The regression results are presented in Table 3. To illustrate how different factors impact the investment choice of mutual funds in the IPO primary market and to increase the robustness of our findings, we run a series of regressions with alternative specifications. In Column 1, we include the variables that are related to the IPO event. In Column 2, we present the results of a model that focuses on the governance variables. In Column 3, the focus of the empirical model is on industry position and firm-specific factors. Finally, the results of a full model that include all the explanatory variables are presented in Column 4.

\footnotetext{
${ }^{15}$ As an alternative, one may also use the weighted number of mutual funds, where the weight is computed as the ratio of a fund's IPO purchase over its total assets. Our results hold up when using this approach as well.
} 
Looking first at the IPO-specific factors, it is clear that the reputation of both the underwriter and the auditor are important determinants when mutual fund managers are considering investing in IPOs. Both Reputable Underwriter and Big4 are significant at the $5 \%$ level in the initial model. In the final regression model, the significance of Reputable Underwriter is somewhat weaker, but the reputation of the underwriter is still influencing mutual funds to invest in an IPO. Both IPO Underpricing and IPO Value are positive and significant at the $1 \%$ level in the initial as well as the full model. The coefficients for P/E Ratio, Offer Price, and Offer Ratio are all negative, but none of them enters significantly into the full model. In Model II, none of the governance variables are significant, and they are all insignificant in the full specification in Model IV. When testing for the significance of Industry Leader in Model 3, we find that it is positively significant at the $1 \%$ level. Moreover, Industry Leader remains positively significant at the $5 \%$ level in the full model, suggesting that industry position influences mutual fund selection.

As expected, both Sales Growth and ROE are positively associated with the choice to invest in new offerings, indicating that the growth trend and profitability are important drivers for mutual funds' IPO investments. Leverage, on the other hand, is negatively associated with IPO stock selection. This relationship is to be expected, as a more leveraged company is typically regarded as a riskier investment. Firm Size is positively associated with IPO investment selection. Again, this is to be expected, as Firm Size is typically positively associated with long-run performance in China (Feng 
et al., 2014). The coefficients for the measure for industry competition, HHI, and Pre 1 Month IPOs are both negative but insignificant.

For completeness, we use the residuals from Model IV to proxy for mutual funds' expectations of IPO firms’ future prospects. ${ }^{16}$

\section{[Table 3 about here]}

\section{Post-IPO Stock Performance}

The initial analysis in the previous section helps us identify important drivers behind the decision to invest in new IPOs by mutual funds in China. Based on the residuals from Model IV in the previous section, we now sort the IPO firms into three separate portfolios: firms with below 33.33\% (low), between $33.33 \%$ and $66.67 \%$ (medium), and above 66.67\% (high) residual mutual funds. The reasoning behind this is that if mutual funds have a superior ability to predict post-IPO performance, then we expect the portfolio with highest residual funds to have the best post-IPO performance. Similarly, we expect the portfolio characterized by the lowest residual mutual fund investment to exhibit the poorest post-IPO performance.

To fully take into account potential weaknesses with different asset pricing models, we use three different approaches to analyze post-IPO stock performance in the sample: buy-and-hold abnormal returns (BHARs); Carhart's (1997) four-factor model, an extension of the Fama-French (1993) three-factor model that also includes

\footnotetext{
${ }^{16}$ Using residuals from models I and III as the underlying expectations of mutual funds does not change the results substantially.
} 
a momentum factor; and Fama-MacBeth’s (1973) panel regression approach. Before we move on to each of the different approaches, we need to define the event window. If the window is too short, there is significant risk that stock performance is affected by investor attention in the secondary market. The number of mutual funds buying in the primary market may attract noise-traders, thereby pushing the price in the secondary market higher. However, investor attention often decreases quickly and the stock price will revert over time. Findings in previous studies on investor attention suggest that the effects of increased investor attention typically do not last for very long (e.g. Barber and Odean, 2008; Kim and Meschke, 2012). To exclude this alternative explanation, we use two alternative event windows: one and three years after the event, respectively, to test our hypothesis. To avoid extreme short-term movements in the secondary market, we also wait until the first trading week after the IPO has taken place. As each year has an average of 252 trading days, the intervals we focus on are $[+6,+257]$ and $[+6,+760]$, respectively.

\subsection{Buy-and-hold Abnormal Returns (BHARs)}

We first analyze stock performance by calculating 1- and 3-year BHARs. Barber and Lyon (1997) and Lyon et al. (1999) suggest that this approach yields wellspecified test statistics for the long-run behavior of stock returns following corporate events, and we therefore use BHARs instead of regular cumulative abnormal returns (CARs). 1- and 3-year BHARs for stock $i$ are calculated by taking the difference 
between the compounded return on the stock and the compounded return on the benchmark:

$$
\begin{aligned}
& 1-\text { year } B H A R_{i}=\prod_{t=6}^{\min (257, \text { stop })}\left(1+r_{i, t}\right)-\prod_{t=6}^{\min (257, \text { stop })}\left(1+r_{m, t}\right), \\
& 3-\text { year } B H A R_{i}=\prod_{t=6}^{\min (760, \text { stop })}\left(1+r_{i, t}\right)-\prod_{t=6}^{\min (760, \text { stop })}\left(1+r_{m, t}\right) .
\end{aligned}
$$

Here, $r_{i, t}$ is the 1-day return including dividends for stock $i$, and $r_{m, t}$ is the 1-day return on the benchmark. Moreover, min(257,stop) and min(760,stop) mean that the BHAR for stock $i$ is calculated up to 257 and 760 trading days after the listing, respectively, or December 31, 2013, which is the last day of data available in this sample, assuming that there are 252 trading days in a year. We use two different indexes as benchmarks. The first one is an equally weighted index composed of all traded companies that have issued A-shares index. The second index is a tradable value weighted index that is also composed of all traded companies that have issued A-shares. In addition to these indexes we also construct a third benchmark, a portfolio created based on firm size and book-to-market ratios. The matching portfolio for each stock is generated in two steps. First, we form quintile breakpoints based on firm size. Second, we sort each stock into five subgroups according to their book-to-market ratios independently. All of the non-IPO firms are then allocated into the resulting 25 portfolios by intersecting the size and book-to-market quintiles. 
The 1- and 3-year BHARs against the different benchmarks are reported in Table 4. Similar to results in earlier studies on post-IPO stock performance (e.g. Loughran and Ritter, 1995; Brav et al., 1997), IPO stocks on average underperform against the different benchmarks. One year after the IPO, newly listed firms have performed on average $38.1 \%$ worse than the equally weighted index, $15.2 \%$ worse than the tradable weighted index, and $7.9 \%$ worse than a matching portfolio based on size and the book-to-market ratio. The underperformance over three years is $68.1 \%$ against the equally weighted index, and 5.2\% against the matching portfolio. The only abnormal return for the full sample that is positive is the 3-year BHAR against the tradable value weighted index, and that is not significantly different from zero.

More importantly, we find that the BHARs differ considerably across the different portfolios. For example, for the 1-year BHAR against the equally weighted index, we find that the underperformance goes from a very high $51.6 \%$ to a much lower $19.5 \%$ for the low and high residual fund investment, respectively. Similarly, for the 3-year BHAR against the equally weighted index, underperformance goes from $72.8 \%$ to $52.4 \%$ for the low and high residual fund investment, respectively. In fact, underperformance decreases from low to high residual fund investment portfolios against all benchmarks and for both time horizons. When the tradable value weighted index and Size and B/M matching portfolio are used as benchmarks, the 3year BHAR for the portfolio with high residual fund investment is actually significantly positive (with a coefficient of 0.141 and 0.127 , respectively). To see if the difference between the low and high residual fund investment is significant, we 
calculate $T$ - and Wilcoxon-Mann-Whitney tests, as shown in the final column. We find that the excess returns for the high residual fund investment sample are significantly higher, regardless of which benchmark we use.

The findings in Table 4 suggest that mutual funds in China are able to predict IPO firm's future prospects. The monotonic decrease as we move from low to high residual funds suggests that, on average, mutual funds are able to pick IPO stocks that will perform well in the future based on information not typically included in the analysis for funds’ buying decision in the IPO market discussed in Section 3.

[Table 4 about here]

\subsection{Carhart's Four-Factor Model}

Next, we apply Carhart’s (1997) four-factor time-series regression approach, which includes Fama and French's (1993) three factors and a momentum factor, to analyze whether or not residual funds can predict post-IPO stock returns. To do this, we use the following empirical model:

$$
R_{p, t}-R_{f, t}=a+b\left(R_{m, t}-R_{f, t}\right)+s S M B_{t}+h H M L_{t}+m U M D_{t}+\varepsilon_{t}
$$

Here, $R_{p, t}$ is the equally weighted returns of the portfolio of IPO firms in month $t ; R_{f, t}$ is the risk-free interest rate in month $t$, calculated based on the 3-month deposit rate set by the People's Bank of China; $R_{m, t}$ is the tradable value weighted index of all A- 
shares in month $t$; $S M B_{t}$ is the difference between the returns on small and large stocks in month $t$; HML $L_{t}$ is the difference between the returns of high and low bookto-market stocks in month $t$. Finally, we include $U M D_{t}$, which is the difference in the return on high and low momentum stocks in month $t$.

We run the regression for each of the three portfolios (low, medium, and high residual funds). For comparison, we also create a zero-investment portfolio, in which we buy high residual funds and short low residual funds. The results of the regression analysis are presented in Table 5 . Here, we focus on the intercept term, $a$, as it represents the excess returns of the different portfolios after controlling for the effects of the various risk factors. For the 1-year regression, we find that the excess returns increase monotonically with the residual funds: for the low residual funds portfolio, the intercept term has a significantly negative value of -0.026 ; for the medium residual funds portfolio, it has significantly negative value of -0.008 , and for the high residual funds portfolio, it has a significantly positive value of 0.002 . The pattern is similar for the 3-year regression, with intercepts of $-0.004,0.002$, and 0.005 for the low, medium, and high residual funds portfolios, respectively.

The regression results for the zero-investment portfolios reinforce these findings. The estimated excess return for the portfolio is 2.8 basis points per month in the 1-year regression. In the 3-year regression, the excess return is estimated to 0.9 basis points per month. These results suggest that IPO firms with low residual funds exhibit significantly poorer post-IPO returns than those with high residual funds. 
[Table 5 about here]

\subsection{Fama-MacBeth Panel Regression}

To further test the ability of mutual funds to identify IPOs with superior future returns, we apply Fama and MacBeth’s (1973) cross-sectional regression approach to the portfolios of IPO firms. The primary motive for using this approach is that it allows us to analyze the robustness of how well residual funds predict post-IPO stock performance by controlling for other determinants, including the quality of underwriters and auditors. First, a cross-sectional regression is performed for each month. Then, the final coefficient estimates are obtained by taking the average of the first step coefficient estimates. Suitable standard errors are then computed for the final coefficients.

Following Loughran and Ritter (1995) and Das et al. (2006), we estimate the following regression model on a sample comprised of all A-share stocks:

$$
\begin{aligned}
& r_{i, t}=\beta_{0}+\beta_{1} \log M V_{i, t}+\beta_{2} \log (B V / M V)_{i, t}+\beta_{3} \text { Issue }_{i, t}+\beta_{4}(\text { Residual Funds } * \\
& \text { Issue })_{i, t}+\beta_{5}(\text { Reputable Underwriter } * \text { Issue })_{i, t}+\beta_{6}(\text { Big } 4 * \text { Issue })_{i, t}+\varepsilon_{i, t} .
\end{aligned}
$$


Here, $M V$ is the market capitalization at the end of the previous year; $B V / M V$ is the book value of equity over the market value of equity at the end of the previous year ${ }^{17}$; Issue is a dummy variable that is equal to one if the firm carried out a public equity issue one year (three years) before when considering the post-IPO performance over one year (three years) and zero otherwise; Residual Funds is the residual from the model on Original Funds in Section 3; and Reputable Underwriter and Big4 are defined the same as in Section 2.2. We include the cross-product term of Reputable Underwriter and Issue because Carter et al. (1998) find that the reputation of the underwriter has an effect on long-run IPO performance. Similarly, it is likely that the quality of the firm's auditor at the time of the IPO affects long-run stock performance and we therefore include the cross-product term of Big4 and Issue in the regression model.

The results of the monthly cross-sectional regressions are presented in Table 6. Column 1 presents the results with the 1-year returns as the dependent variable, while Column 2 presents the results with 3-year returns as the dependent variable. The results for the two windows of return are quite similar. All explanatory variables except for the interaction variable Big4*Issue are significant. The logarithm of MV and BV/MV are both significantly negative, suggesting that they are indeed important determinants for long-run post-IPO stock performance. As expected, the interaction variable between Issue and Reputable Underwriter is significantly positive, suggesting

\footnotetext{
${ }^{17}$ For a discussion on the use of $M V$ and $B V / M V$ in the modeling of stock returns, see Daniel and Titman (1997).
} 
that the reputation of the underwriter affects long-run post-IPO performance. More importantly, the cross-product term of Issue and Residual Funds is positive and significant. The positive relationship between residual funds and post-IPO long-run performance is robust over the different return windows. This finding again suggests that ex ante underlying expectations of IPO firm's future prospects can predict the post-IPO stock performance ex post. Based on these results, we can argue that the mutual funds have stock picking ability in the IPO primary market.

[Table 6 about here]

\section{Post-IPO Operating Performance}

To shed more light on the ability of mutual funds to identify outperforming firms, we analyze operating performance during three years after the IPO. We do this for each of the subgroups, i.e. the portfolios composed of firms with low, medium, and high residual funds, respectively. Here, we analyze return on assets (ROA), measured as net income over total assets over one, two, and three years after the IPO for the three subsamples low, medium, and high residual funds, respectively. For robustness, we also study the effects on return on sales (ROS), measured as net income over total sales, and return on equity (ROE), measured as net income over shareholder's equity, over these three time horizons. To control for a potential industry-related bias in the sample, we also compute and present results for industryadjusted performance measures across all time horizons. Finally, as pointed out by 
Jain and Kini (1994), performance measures may be skewed. In an effort to minimize this potential issue, we also provide median values of the different measures.

The different measures of operating performance are presented in Table 7. Looking first at the ROA measures, operating performance increases monotonically as we move from low (0.060) to medium (0.073) to high (0.081) residual funds portfolios for the 1-year window. Similarly, ROA increases when we move across the three portfolios using the 2-, and 3-year windows. Moreover, when we adjust the measures to take industry characteristics into account, these results hold as ROA increases monotonically across the three portfolios and for all time horizons. To test the significance in the difference between the low and high residual funds portfolios, we also include a T-test and a Wilcoxon-Mann-Whitney test. The tests show that the difference is significant at the $5 \%$ level in all cases, and at the $1 \%$ level in a majority of them.

Moving on to the alternative operating performance measures, the results above hold up well. ROS and ROE increase monotonically from low to medium to high residual funds portfolios regardless of which time horizon we look at. When we compare the difference in ROS and ROE for the low and high residual funds portfolios, we find that the difference is significant at, at least, the $5 \%$ level in all cases. Again, the difference between the mean and median of these two subsamples is significant at the $1 \%$ level in a majority of the cases. Finding that the superior performance of the high residual mutual fund investment holds across different operating performance measures, time horizons, and industry adjustment, we can 
conclude that mutual funds in China are more prone to invest in IPO firms that are going to perform relatively better than other IPO firms.

[Table 7 about here]

\section{Robustness Checks}

\subsection{Controlling for Governance Effects}

Although the results above are interesting, concerns may still be raised regarding our baseline results. While we argue that mutual funds as a group are able to identify good investment opportunities in the primary market, previous studies have argued that mutual funds may prefer well-governed firms that perform better in the future. To take this into account, we have controlled for this alternative explanation for excess post-IPO returns by adding a set of governance variables when discussing residual funds.

To further reduce this concern, we use a double-sort portfolio approach to examine the joint effect of fund stock selection and firm's governance factors on IPO long-run performance. Table 8 presents the 3-year BHARs conditional on different corporate governance factors. ${ }^{18}$ We first divide IPO firms by whether the ultimate owner controls the firm through a pyramidal structure, and then again sort them into

\footnotetext{
${ }^{18}$ The results for 1-year BHARs and operating performance are qualitatively similar. We do not present them for the sake of brevity. We use independent double sorting to divide the sample. Sequential double sorting gives similar results.
} 
three groups by residual funds independently. By doing so, we obtain 2x3 portfolios. Panel A in Table 8 presents the BHARs for these different portfolios. We find that, for firms characterized by pyramid structures, BHARs increase with residual funds and the difference between portfolios with high residual funds and portfolios with low residual funds is significantly positive. For firms not characterized by pyramid structures, a positive relation between BHARs and residual funds is also observed. This means that mutual funds' underlying expectations about IPO firms can predict firm prospect for both types of firms. Because our 2x3 portfolios are formed independently, we can also analyze the relationship between the BHARs and the existence of pyramid ownership. It has been argued that pyramidal structures indicate poor corporate governance. Such firms should thus exhibit inferior performance, ceteris paribus, if pyramid ownership plays a dominant role. We indeed find that portfolios with firms characterized by pyramid ownership exhibit smaller BHARs than portfolios with firms that are not characterized by pyramid ownership in the groups with low residual funds, medium residual funds, and high residual funds. However, the difference is not statistically significant. We can therefore conclude that corporate governance from the perspective of pyramidal ownership structure is not driving the results in the previous sections.

Panel B in Table 8 presents the BHARs for 2x3 portfolios based on residual funds and whether or not an IPO firm's CEO is also the Chairman of the Board. Again, we find that BHARs increase monotonically with residual funds for both firms characterized by dual positions and firms without this characteristic, supporting our 
hypothesis. However, the BHARs for firms not characterized by dual positions are smaller than the ones with CEOs who are also Chairman of the Board, although the difference is not significant for the group with low, median, and high residual funds. These results once again show that corporate governance, this time from the perspective of non-duality, is not driving our previous findings.

Panel C in Table 8 presents the BHARs for 2x3 portfolios based on residual funds and whether or not IPO firm's ratio of independent directors is larger than the sample median value. In the below median independent directors group, BHARs increase with residual funds and the BHAR difference between high residual funds portfolios and low residual funds portfolios is significant. This means that the consensus opinion of mutual funds on the prospects of IPO firms predict firms' future performance irrespective of the ratio of independent directors. Although portfolios with low independent directors have higher BHARs than portfolios with more independent directors, there is no significant difference between them. Independent directors thus have almost no impact on BHARs for equal residual funds.

Panel D in Table 8 presents the BHARs for 2x3 portfolios based on residual funds and whether or not other institutional shareholders' holdings are larger than the sample median value. Again, the BHARs are positively related with the residual funds in both the group composed of firms characterized by lower holdings of other institutional shareholders and the one characterized by higher such holdings. The effect of other institutions on IPO firms' future performance is insignificant, suggesting that the degree of institutional shareholders' holdings does not have a 
significant impact on BHARs for IPOs characterized by equal residual funds.

Panel E in Table 8 presents the BHARs for 2x3 portfolios based on residual funds and whether or not the largest shareholders' holding is larger than the sample median value. The difference in the BHARs is still significant for the portfolio of firms characterized by lower holdings of the largest shareholder. Moreover, largest ownership does not significantly influence our results.

Finally, Panel F in Table 8 presents the BHARs for 2x3 portfolios based on residual funds and whether or not the IPO firm is a private firm. Again, BHARs increase with residual funds either in the group that is only composed of private firms or the group only composed of non-private firms. The results hold up regardless of whether the ultimate owner is a private person or the state. Based on the results in Table 8, we can conclude that even after taking different governance factors into account, the relationship between BHARs and residual funds is still positive and significant. These results are expected, as residual funds in this study by design are orthogonalized to all governance measures discussed here. Moreover, using the residuals from the models I and III in Table 3 to analyze good governance preference also does not change our main findings.

[Table 8 about here]

There is also a possibility that stock picking and monitoring are two sides of the same coin. After mutual funds invest in an IPO firm, they stay in the firm and 
possibly monitor its management. This makes it difficult to disentangle the stock selection effect from the monitoring effect. In line with this reasoning, Yuan et al. (2008) suggest that mutual funds in China have begun to play a positive role in terms of corporate governance. We therefore need to eliminate the monitoring story before confirming our conclusion. The prerequisite for the existence of the governance effect is that mutual funds have an ownership in a firm over a longer period. This reasoning is based on Chen et al. (2007), who argue that only institutional investors with a longterm horizon can specialize in monitoring and exert efforts to influence management, and that short-time investors are often passive and vote with their feet by exiting poorly performing firms. Since funds with high turnover on average hold stocks for a shorter time and thus are less likely to actively monitor management, their governance role should be limited.

To gauge the possible impact of post-IPO monitoring, we look at the decision by mutual funds to hold on to or to divest their IPO shares. We again divide the sample into three groups based on low, medium and high funds. To analyze post-IPO holding patterns, we measure the turnover ratio as the ratio of the total amount of purchase and sale transactions to a fund's stock holdings. The turnover for the three sample groups are presented in Table 9. It is clear that the mutual fund sample is characterized by a very high turnover, ranging from $228.35 \%$ to $487.90 \%$ depending on sample group. We argue that these very high turnover ratios across the sample reduce the concern that mutual funds will have a significant monitoring effect on newly listed firms in China. 
It could be argued that, although turnover can measure a funds' holding period in general, it is not a perfect measure when it comes to analyzing the monitoring role for IPO firms. After the three-month lock-up period, mutual funds are allowed to sell their IPO stock in the market. The longer mutual funds hold an IPO stock, the more likely it is that it will exert a governance role. Heavy selling of shares then indicates a small likelihood that a mutual fund will influence management. To shed further light on the potential monitoring effect of mutual fund investments in Chinese IPO, we therefore measure the sell ratio after one year (three years), which we define as the number of mutual funds that aggressively sell off IPO stocks one year (three years) after the IPO divided by the total number of funds which purchase it in the primary. ${ }^{19}$ Thus, a higher sell ratio indicates a lower likelihood of monitoring. As seen in Table 9, we find that most mutual funds begin to sell off IPO stocks aggressively one year after the IPO event. We therefore argue that the prerequisite for an influential monitoring effect does not exist. The sell ratio after three years supports this argument, with very high ratios ranging from $75.64 \%$ to $95.19 \%$. Moreover, the fact that the sell ratio after one year (three years) increases with the residual funds speaks against the monitoring story, although the difference between portfolios with high residual funds and portfolios with low residual funds is only significant at the $5 \%$ level for the median of the post-IPO one-year ratio and at the $10 \%$ level for mean of the post-IPO three year ratio. We can thus conclude that the monitoring story does not drive our

\footnotetext{
${ }^{19}$ In this study, heavy selling is defined as the ratio of total selling over its original holdings being larger than $20 \%$. Our results are consistent when we use other thresholds such as $5 \%, 10 \%, 30 \%$ or $50 \%$.
} 
results.

[Table 9 about here]

\subsection{Other Robustness Checks}

We control for a number of additional issues that may result in biased results. First, we recognize the fact that some mutual funds are managed by the same fund manager. This may affect the variable Original Funds, which in turn has the potential to bias our results, since if we focus on the stock picking ability of managers, then the phenomenon of one-manager-many-funds may exaggerate managers’ stock picking skills. We therefore count the different funds of one fund manager as one and redo the regression again, after which we find that the results are qualitatively the same. Checking the data, we also find that mutual funds from one family often buy the same IPO firm simultaneously. We therefore run additional tests in which we count all funds from one family as one, considering that organization capital may have a strong influence on mutual funds' stock picking ability. When doing this, we still find a significant relationship between residual funds and performance. Our conclusions thus hold regardless of whether we discuss the source of mutual funds' stock picking ability in terms of individual mangers or in terms of a whole fund family.

Second, we recognize that some of the initial mutual fund investments are done by funds that predominately focus on the bond market. The proportion of such 
funds stands at $27.35 \%$ in our sample. To take this into account, we rerun the tests for a sample that excludes these funds. We find that the relationship between IPO firms with high residual funds and superior performance is consistent. Third, we recognize the fact that about half of the IPOs in our sample took place in 2010. To check that the IPOs in that year did not drive the results, we run the tests without the IPOs in 2010, after which the results again remained qualitatively the same. Fourth, it can be argued that the choice to divide the sample into tertiles is somewhat arbitrary. To control for this, we also divide the sample into medians, quartiles, quintiles, and deciles. The results turn out to be qualitatively very similar. We can thus conclude that none of these potential issues are driving our main findings.

\section{Conclusion}

In this paper, we examine the ability of mutual funds to select IPO firms in China during the period 2005-2010. Applying a two-step methodology, we propose that residuals from an empirical framework in which we model the number of mutual funds buying in the IPO primary market on a set of typically used determinants can proxy the underlying expectations on IPO firms' future prospects. It can thus be used to test the existence of mutual funds’ stock picking ability.

We use various alternative ways to identify post-IPO performance, including buy-and-hold abnormal returns (BHARs), Carhart's four-factor model, and FamaMacBeth's panel regression approach. Our results show that residual funds are significantly and positively associated with post-IPO stock returns over both 1- and 3- 
year time horizons. We then analyze post-IPO operating performance using return on assets (ROA), return on sales (ROS), and return on equity (ROE). We find that there is a significant and positive relationship between residual funds and all of the various measures of operating performance across different time horizons. We then provide evidence that mutual funds' preference for well-governed IPO firms cannot explain our findings. The prerequisite for the monitoring effect does not exist because mutual funds typically hold stock for shorter periods. The fact that we find differences in the holding period between portfolios with high residual funds and portfolios with low residual funds, with high residual funds portfolio being characterized by shorter holding periods, actually strengthen our baseline results. Thus, the alternative story of improved corporate governance as a main driver behind post-IPO performance cannot explain our findings. Finally, we control for a number of potential issues that may bias our results, after which we still find that residual funds are significantly and positively related to post-IPO firm performance. We therefore argue that portfolios composed of IPO firms that are deemed to be better investments by mutual funds, what we call the high residual funds portfolio, consistently outperform corresponding portfolios composed of firms that are characterized by low residual funds.

Our findings are consistent with the hypothesis that the consensus expectations of mutual funds in the IPO market can predict IPO firms' future performance. This result has direct and important implications for individual investors looking into the possibility of investing in new public offerings in China. 


\section{References}

Aharony, J., Lee, C.-W.J., Wong, T.J., 2000. Financial Packaging of IPO Firms in China. Journal of Accounting Research 38, 103-126.

Bai, C.-E., Liu, Q., Lu, J., Song, F.M., Zhang, J., 2004. Corporate Governance and Market Valuation in China. Journal of Comparative Economics 32, 599-616.

Barber, B.M., Lyon, J.D., 1997. Detecting Long-Run Abnormal Stock Returns: The Empirical Power and Specification of Test Statistics. Journal of Financial Economics 43, 341-372.

Barber, B.M., Odean, T.M., 2008. All That Glitters: The Effect of Attention and News on the Buying Behavior of Individual and Institutional Investors. Review of Financial Studies 21, 785-818.

Beatty, R., 1989. Auditor Reputation and the Pricing of Initial Public Offerings. Accounting Review 64, 693-709.

Benveniste, L., Spindt, P., 1989. How Investment Bankers Determine the Offer Price and Allocation of New Issues. Journal of Financial Economics 24, 343-361.

Brav, A., Gompers, P., 1997. Myth or Reality? The Long-Run Underperformance of Initial Public Offerings: Evidence from Venture Capital and Non-Venture-Backed Companies. Journal of Finance 52, 1791-1821.

Carhart, M., 1997. On Persistence in Mutual Fund Performance. Journal of Finance 52, 57-82.

Carter, R., Dark, F.H., Singh, A.K., 1998. Underwriter Reputation, Initial Returns, and the Long-Run Performance of IPO Stocks. Journal of Finance 53, 285-311.

Carter, R., Manaster, S., 1990. Initial Public Offerings and Underwriter Reputation. Journal of Finance 45, 1045-1067.

Chan, K., Wang, J., Wei, K., 2004. Underpricing and Long-Term Performance of IPOs in China. Journal of Corporate Finance 10, 409-430.

Chen, G., Firth, M., Gao, D.N., Rui, O.M., 2006. Ownership Structure, Corporate Governance, and Fraud: Evidence from China. Journal of Corporate Finance 12, 424448. 
Chen, X., Harford,J., Li,K., 2007. Monitoring: Which Institutions Matter? Journal of Financial Economics 86, 279-305.

Cheng, C.S.A, Huang, H.H., Li, Y., Lobo, G., 2010. Institutional Monitoring through Shareholder Litigation. Journal of Financial Economics 95, 356-383.

Cheung, Y., Ouyang, Z., Tan, W., 2009. How Regulatory Changes Affect IPO UnderPricing in China. China Economic Review 20, 692-702.

Claessens, S., Djankov, S., Lang, L.P.H., 2000. The Separation of Ownership and Control in East Asian Corporations. Journal of Financial Economics 58, 81-112.

CSRC, 2006. Measures for the Administration of Initial Public Offering and Listing of Stocks. (In Chinese) www.csrc.gov.cn/pub/zjhpublic/G00306201/200907/ P020090713355768758923.doc

CSRC, 2009. Administrative Measures for Initial Public Offerings and Listing on the Second Board. (In Chinese)

http://www.csrc.gov.cn/pub/newsite/cyb/tzgg/201011/t20101116_187348.htm

Das, S., G., R.-J., Zhang, H., 2006. Analysts' Selective Coverage and Subsequent Performance of Newly Public Firms. Journal of Finance 61, 1159-1185.

Dasgputa, S., Hansen, R.G., 2007. Auctions in Corporate Finance. In Eckbo, B.E. (Ed.), Handbook of Empirical Corporate Finance, Chapter 3. Amsterdam: Elsevier/North Holland.

Elton, E., Gruber, M., Das, S., Hlavka, M., 1993. Efficiency with Costly Information: A Reinterpretation of Evidence for Managed Portfolios. Review of Financial Studies 6, 1-22.

Fama E., French, K., 1993. Common Risk Factors in the Returns on Stocks and Bonds. Journal of Financial Economics 33, 3-56.

Fama E., French. K., 2010. Luck Versus Skill in the Cross-Section of Mutual Fund Returns. Journal of Finance 65, 1915-1947.

Fama, E., MacBeth. J., 1973. Risk, Return, and Equilibrium: Empirical Tests. Journal of Political Economy 81, 607-636.

Fan, J.P.H., Wong, T.J., Zhang, T., 2007. Politically Connected CEOs, Corporate Governance, and Post-IPO Perfomance of China's Newly Partially Privatized Firms. Journal of Financial Economics 84, 330-357. 
Feng, X., Johansson, A.C., Zhang, T., 2014. Political Participation and Entrepreneurial Initial Public Offerings in China. Journal of Comparative Economics 42, 269-285.

Francis, B., Hasan, I., Sun, X., 2009. Political Connections and the Process of Going Public: Evidence from China. Journal of International Money and Finance 28, 696719.

Gillan, S.L., Kensinger, J.W., Martin, J.D., 2000. Value Creation and Corporate Diversification: The Case of Sears, Roebuck \& Co. Journal of Financial Economics 55, 103-137.

Goetzmann, W., Ibbotson, R., 1994. Do Winners Repeat? Journal of Portfolio Management 20, 9-18.

Gruber, M., 1996. Another Puzzle: The Growth in Actively Managed Mutual Funds. Journal of Finance 51, 783-810.

Grinblatt, M., Titman, S., 1993. Performance Measurement without Benchmarks: An Examination of Mutual Fund Returns. Journal of Business 66, 97-112.

Grinblatt, M., Titman, S., 1989. Mutual Fund Performance: An Analysis of Quarterly Portfolio Holdings. Journal of Business 62, 394-415.

Grinblatt, M., Titman , S., Wermers, R., 1995. Momentum Investment Strategies, Portfolio Performance, and Herding: A Study of Mutual Fund Behavior. American Economic Review 85, 1088-1105.

Hendricks, D., Patel, J., Zeckhauser, R., 1993. Hot Hands in Mutual Funds: Short-Run Persistence of Relative Performance, 1974-1988. Journal of Finance 48, 93-130.

Hong, H., Lim, T., Stein, T.C., 2000. Bad News Travels Slowly: Size, Analyst Coverage, and the Profitability of Momentum Strategies. Journal of Finance 55, 265295.

Jain, B., Kini, O., 1994. The Post-Issue Operating Performance of IPO Firms. Journal of Finance 49, 4699-4726.

Jensen, M.C., 1968. The Performance of Mutual Funds in the Period 1945-1964. Journal of Finance 23, 389-416. 
Jensen, M.C., 1993. Presidential Address: The Modern Industrial Revolution, Exit and the Failure of Internal Control Systems. Journal of Finance 48, 831-880.

Jian, M., Wong, T.J., 2010. Propping through Related Party Transactions. Review of Accounting Studies 15, 70-105.

Jiang, G., Lee, C.M.C., Yue, H., 2010. Tunneling through Inter-Corporate Loans: The China Experience. Journal of Financial Economics 98, 1-20.

Johnson, S., La Porta, R., Lopez-de-Silanes, F., Shleifer, A., 2000. Tunneling. American Economic Review 90: 22-7.

Kacperczyk, M., Sialm, C., Zheng, L., 2008. Unobserved Actions of Mutual Funds. Review of Financial Studies 21, 2379-2416.

Kacperczyk, M., Seru, A., 2007. Fund Manager Use of Public Information: New Evidence on Managerial Skills. Journal of Finance 62, 485-528.

Kim, Y.H.A., Meschke, F., 2012. CEO Interviews of CNBC. NTU Working Paper.

La Porta, R.,Lopez-de-Silanes, F., Shleifer, A., 1999. Corporate Ownership around the World. Journal of Finance 54, 471-518.

Ljungqvist, A., Wilhelm, W., 2002. IPO Allocations: Discriminatory or Discretionary? Journal of Financial Economics 65, 167-201.

Loughran, T., 1993. NYSE vs NASDAQ Returns: Market Microstructure or the Poor Performance of Initial Public Offerings? Journal of Financial Economics 33, 241260.

Loughran, T., Ritter, J.R., 1995. The New Issues Puzzle. Journal of Finance 50, 2351.

Lyon, J., Barber, B., Tsai, C., 1999, Improved Methods for Tests of Long-Run Abnormal Stock Returns. Journal of Finance 54, 165-201.

Malkiel, B., 1995. Returns from Investing in Equity Mutual Funds 1971 to 1991. Journal of Finance 50, 549-572.

Michaely, R., Shaw, W.H., 1995. Does the Choice of Auditor Convey Quality in an Initial Public Offering? Financial Management 24, 15-30. 
Miller, R.E., Reilly, F., 1987. An Examination of Mispricing, Returns, and Uncertainty for Initial Public Offerings. Financial Management 16, 33-38.

Rechner, P.L., Dalton, D.R., 1991. CEO Duality and Organizational Performance: A Longitudinal Analysis. Strategic Management Journal 12, 155-160.

Ritter, J.R., 1984. The 'Hot Issue’ Market of 1980. Journal of Business 32, 215-240.

Ritter, J.R., 1991. The Long-Run Performance of Initial Public Offerings. Journal of Finance 46, 3-27.

Rock, K., 1986. Why New Shares Are Underpriced. Journal of Financial Economics 15, 187-212.

Sherman, A., Titman, S., 2002. Building the IPO Order Book: Underpricing and Participation Limits with Costly Information. Journal of Financial Economics 65, 329.

Tenev, S., Zhang, C., Brevort, L., 2002. Corporate Governance and Enterprise Reform in China: Building the Institutions of Modern Markets. Washington DC: World Bank and the International Finance Corporation.

Tian, L., Megginson, W.L., 2007. Regulatory Underpricing: Determinants of Chinese Extreme IPO Returns. University of Oklahoma, Working Paper.

Tinic, S., 1988. Anatomy of Initial Public Offerings of Common Stock. Journal of Finance 43, 789-822.

Titman, S., Trueman, B., 1986, Information Quality and the Valuation of New Issues. Journal of Accounting and Economics 8, 159-172.

Tsai, E.S., 2007. Capitalism without Democracy: The Private Sector in Contemporary China. Ithaca, NY: Cornell University Press.

Wei, Z., Xie, F., Zhang, S., 2005. Ownership Structure and Firm Value in China's Privatized Firms: 1991-2001. Journal of Financial and Quantitative Analysis 40, 87108.

Wermers, R., 1997. Momentum Investment Strategies of Mutual Funds, Performance Persistence, and Survivorship Bias. University of Colorado at Boulder, Working Paper. 
Wermers, R., 2000. Mutual Fund Performance: An Empirical Decomposition into Stock-Picking Talent, Style, Transaction Costs, and Expenses. Journal of Finance 55, 1655-1695.

Woidtke, T., 2002. Agents Watching Agents? Evidence from Pension Fund Ownership and Firm Value. Journal of Financial Economics 63, 99-131.

Yu, T., Tse, Y., 2006. An Empirical Examination of IPO Underpricing in the Chinese A-Share Market. China Economic Review 17, 363-82. 


\section{Table 1. IPO Sample}

\section{Panel A. Year Distribution of Chinese IPOs}

This panel describes the year distribution of the sample of initial public offerings during the sample period 2005-2010. Column 2 reports the number of IPOs in a given year and Column 3 reports the percentage of IPOs in a given year of the total sample.

\begin{tabular}{lcc}
\hline Year & Sample & Percentage \\
\hline 2005 & 14 & $1.93 \%$ \\
2006 & 65 & $8.98 \%$ \\
2007 & 123 & $16.99 \%$ \\
2008 & 76 & $10.50 \%$ \\
2009 & 99 & $13.67 \%$ \\
2010 & 347 & $47.93 \%$ \\
Total & 724 & $100 \%$ \\
\hline
\end{tabular}


Table 1. IPO Sample (Continued)

Panel B. Industry Distribution of Chinese IPOs 2005-2010

This panel presents the industry distribution of IPOs in China during the period 20052010.

\begin{tabular}{lcc}
\hline \multicolumn{1}{c}{ Industry } & Sample & Percentage \\
\hline Agriculture, Forestry, farming \& fishery & 14 & $1.93 \%$ \\
Mining & 18 & $2.49 \%$ \\
Food \& Beverage & 21 & $2.90 \%$ \\
Textiles \& Apparel & 22 & $3.04 \%$ \\
Timber \& Furnishings & 5 & $0.69 \%$ \\
Paper \& Printing & 18 & $2.49 \%$ \\
Petrochemicals & 83 & $11.46 \%$ \\
Electronics & 68 & $9.39 \%$ \\
Metals \& Non-metals & 60 & $8.29 \%$ \\
Machinery & 160 & $22.10 \%$ \\
Pharmaceuticals & 35 & $4.83 \%$ \\
Other manufacturing & 12 & $1.66 \%$ \\
Utilities & 8 & $1.10 \%$ \\
Construction & 19 & $2.62 \%$ \\
Transportation & 17 & $2.35 \%$ \\
Information Technology & 81 & $11.19 \%$ \\
Whole sale \& Retail Trade & 19 & $2.62 \%$ \\
Finance & 19 & $2.62 \%$ \\
Real estate & 8 & $1.10 \%$ \\
Social Services & 23 & $3.18 \%$ \\
Communication \& Culture & 11 & $1.52 \%$ \\
Conglomerate & 3 & $0.41 \%$ \\
Total & 724 & $100 \%$ \\
\hline
\end{tabular}




\section{Table 2. Descriptive Statistics}

This table provides descriptive statistics for the full sample and as well as subsamples of IPO firms with low, medium, and high mutual funds based on the number of mutual funds that invest in the IPOs (below the 33.3 and 66.7, and above the 66.7 percentile, respectively). Original Funds is measured as the number of mutual funds that invest in a new firm in the IPO primary market. Reputable Underwriter is a dummy variable that equals one when the total amount of the IPO shares sold or the total number of IPO firms it underwrote places it in the top 10\% during the three years previous to the IPO, and zero otherwise. Big4 is a dummy variable equals one when the auditor is one of the big 4 international accounting firms (PWC, Ernst \& Young, $\mathrm{DTT}$, or KPMG) and zero otherwise. IPO underpricing is measured as the difference between the closing price on the first trading day and the offering price, divided by the offering price. IPO value is measured as the natural logarithm of the offering size. $P / E$ Ratio is measured as the ratio of the offering price to earnings per share (EPS), where EPS is the ratio of the average annual earnings during three years before the IPO to the total number of post-offering shares. Offer Price is measured as the offer price for IPO firm. Offer Ratio is measured as the ratio of the new shares offered in the primary market to total shares. Largest ownership is measured as the percentage ownership of the largest shareholder. Pyramid is a dummy that equals one if the ultimate owner controls the listed firm through at least one firm, and zero otherwise. Non-Duality is a dummy which equals one if the CEO is not the Chair of Board, and zero otherwise. Independent Directors is measured as the ratio of independent directors on the board. Other Institutions is the ratio of other institutional shareholders' aggregate holdings over total shares, where such institutions refer to VC/PE firms, pension funds, trust funds, insurance companies, and assets management products from brokerage houses. Private Firm is a dummy variable that equals one when its ultimate owner is a private investor or family, and zero otherwise. Industry Leader is an indicator for whether the firm is an industry leader, measured as whether the sales of IPO firm ranked as top 30\% in its industry. Sales Growth is measured as the average ratio of the sales growth rate during three years prior to the IPO. ROE is measured as the average ratio of return on equities during three years prior to the IPO. Leverage is measured as the average ratio of total long-term and short-term debt to total assets during three years prior to the IPO. Firm Size is measured as the average value of the natural logarithm of total assets during three years prior to the IPO. Sales Growth, ROE, and Leverage and Firm Size are all further adjusted by industry based on CSRC industry standards. HHI (Herfindahl-Hirschman Index) is an indicator of competition, estimated using all listed firms' sales from the same industry just before the IPO year. Pre 1 Month IPOs is measured as the number of new IPOs during the last month prior to the IPO. Small and Median Board Growth is a dummy variable that equals one for IPOs listed on the Small and Median Board Growth board, and zero otherwise. Growth Enterprise Board is a dummy variable that equals one for IPOs listed on the Growth Enterprise Board, and zero otherwise. All continuous variables are winsorized at top and bottom 1\%. T-tests and Wilcoxon-Mann-Whitney tests are provided for the 
mean and median comparison of Low Funds sample with and High Funds sample. $* * *, * *$, and $*$ denote significance at the $1 \%, 5 \%$ and $10 \%$ level, respectively.

\begin{tabular}{|c|c|c|c|c|c|}
\hline & $\begin{array}{c}\text { Full } \\
\text { Sample }\end{array}$ & $\begin{array}{l}\text { Low } \\
\text { Funds }\end{array}$ & $\begin{array}{l}\text { Median } \\
\text { Funds }\end{array}$ & $\begin{array}{l}\text { High } \\
\text { Funds }\end{array}$ & $\begin{array}{l}\text { T-test } \\
\text { (W-M-W } \\
\text { test) }\end{array}$ \\
\hline Original Funds & $\begin{array}{c}41.68 \\
(33.00)\end{array}$ & $\begin{array}{c}10.84 \\
(11.00)\end{array}$ & $\begin{array}{c}33.42 \\
(33.00)\end{array}$ & $\begin{array}{c}80.37 \\
(74.00)\end{array}$ & $\begin{array}{c}41.25^{* * *} \\
\left(18.88^{* * *}\right)\end{array}$ \\
\hline Reputable Underwriter & $\begin{array}{c}0.20 \\
(0.00)\end{array}$ & $\begin{array}{c}0.16 \\
(0.00)\end{array}$ & $\begin{array}{c}0.18 \\
(0.00)\end{array}$ & $\begin{array}{c}0.25 \\
(0.00)\end{array}$ & $\begin{array}{c}2.53^{* *} \\
\left(2.51^{* *}\right)\end{array}$ \\
\hline Big 4 & $\begin{array}{c}0.07 \\
(0.00)\end{array}$ & $\begin{array}{c}0.03 \\
(0.00)\end{array}$ & $\begin{array}{c}0.06 \\
(0.00)\end{array}$ & $\begin{array}{c}0.13 \\
(0.00)\end{array}$ & $\begin{array}{c}3.79 * * * \\
(3.74 * * *)\end{array}$ \\
\hline IPO underpricing & $\begin{array}{c}0.839 \\
(0.601)\end{array}$ & $\begin{array}{c}0.531 \\
(0.393)\end{array}$ & $\begin{array}{r}0.730 \\
(0.694)\end{array}$ & $\begin{array}{r}1.256 \\
(0.878)\end{array}$ & $\begin{array}{c}9.41 * * * \\
(9.25 * * *)\end{array}$ \\
\hline IPO value & $\begin{array}{c}20.339 \\
(20.202)\end{array}$ & $\begin{array}{c}20.271 \\
(20.054)\end{array}$ & $\begin{array}{r}20.303 \\
(20.187)\end{array}$ & $\begin{array}{r}20.444 \\
(20.446)\end{array}$ & $\begin{array}{c}1.71^{*} \\
\left(3.85^{* * *}\right)\end{array}$ \\
\hline P/E Ratio & $\begin{array}{c}45.817 \\
(42.419)\end{array}$ & $\begin{array}{c}49.910 \\
(48.029)\end{array}$ & $\begin{array}{r}47.185 \\
(46.479)\end{array}$ & $\begin{array}{r}40.451 \\
(39.079)\end{array}$ & $\begin{array}{c}4.02 * * * \\
(4.82 * * *)\end{array}$ \\
\hline Offer Price & $\begin{array}{c}21.589 \\
(18.000)\end{array}$ & $\begin{array}{c}23.112 \\
(21.290)\end{array}$ & $\begin{array}{r}22.789 \\
(19.530)\end{array}$ & $\begin{array}{r}18.890 \\
(13.870)\end{array}$ & $\begin{array}{c}3.05^{* * *} \\
(4.98 * * *)\end{array}$ \\
\hline Offer Ratio & $\begin{array}{c}0.25 \\
(0.25)\end{array}$ & $\begin{array}{c}0.25 \\
(0.25)\end{array}$ & $\begin{array}{c}0.25 \\
(0.25)\end{array}$ & $\begin{array}{c}0.24 \\
(0.25)\end{array}$ & $\begin{array}{c}0.91 \\
(0.65)\end{array}$ \\
\hline Largest Ownership & $\begin{array}{c}0.44 \\
(0.38)\end{array}$ & $\begin{array}{c}0.52 \\
(0.37)\end{array}$ & $\begin{array}{c}0.39 \\
(0.38)\end{array}$ & $\begin{array}{c}0.40 \\
(0.40)\end{array}$ & $\begin{array}{c}0.89 \\
(0.86)\end{array}$ \\
\hline Pyramid & $\begin{array}{c}0.568 \\
(1.000)\end{array}$ & $\begin{array}{c}0.508 \\
(1.000)\end{array}$ & $\begin{array}{c}0.554 \\
(1.000)\end{array}$ & $\begin{array}{c}0.643 \\
(1.000)\end{array}$ & $\begin{array}{c}1.03 \\
(0.97)\end{array}$ \\
\hline Non-Duality & $\begin{array}{c}0.636 \\
(1.000)\end{array}$ & $\begin{array}{c}0.583 \\
(1.000)\end{array}$ & $\begin{array}{c}0.648 \\
(1.000)\end{array}$ & $\begin{array}{c}0.679 \\
(1.000)\end{array}$ & $\begin{array}{c}2.20^{* *} \\
(2.19 * *)\end{array}$ \\
\hline Independent Directors & $\begin{array}{c}0.365 \\
(0.333)\end{array}$ & $\begin{array}{c}0.362 \\
(0.333)\end{array}$ & $\begin{array}{c}0.364 \\
(0.333)\end{array}$ & $\begin{array}{c}0.370 \\
(0.333)\end{array}$ & $\begin{array}{c}1.48 \\
(0.98)\end{array}$ \\
\hline Other Institutions & $\begin{array}{c}0.040 \\
(0.038)\end{array}$ & $\begin{array}{c}0.041 \\
(0.042)\end{array}$ & $\begin{array}{c}0.040 \\
(0.038)\end{array}$ & $\begin{array}{c}0.038 \\
(0.037)\end{array}$ & $\begin{array}{c}1.44 \\
(1.29)\end{array}$ \\
\hline Private Firm & $\begin{array}{c}0.78 \\
(1.00)\end{array}$ & $\begin{array}{c}0.85 \\
(1.00)\end{array}$ & $\begin{array}{c}0.77 \\
(1.00)\end{array}$ & $\begin{array}{c}0.70 \\
(1.00)\end{array}$ & $\begin{array}{c}0.94 \\
(0.88)\end{array}$ \\
\hline Industry Leader & $\begin{array}{c}0.133 \\
(0.000)\end{array}$ & $\begin{array}{c}0.102 \\
(0.000)\end{array}$ & $\begin{array}{c}0.133 \\
(0.000)\end{array}$ & $\begin{array}{c}0.164 \\
(0.000)\end{array}$ & $\begin{array}{c}2.38 * * \\
(2.37 * *)\end{array}$ \\
\hline Sales Growth ${ }_{\text {ind Ajdusted }}$ & $\begin{array}{c}0.14 \\
(0.06)\end{array}$ & $\begin{array}{c}0.09 \\
(0.031)\end{array}$ & $\begin{array}{c}0.13 \\
(0.10)\end{array}$ & $\begin{array}{c}0.19 \\
(0.17)\end{array}$ & $\begin{array}{l}3.22 * * * \\
\left(2.43^{* *}\right)\end{array}$ \\
\hline$R O E_{\text {ind Ajdusted }}$ & $\begin{array}{c}0.11 \\
(0.10)\end{array}$ & $\begin{array}{c}0.08 \\
(0.05)\end{array}$ & $\begin{array}{c}0.11 \\
(0.10)\end{array}$ & $\begin{array}{c}0.15 \\
(0.11)\end{array}$ & $\begin{array}{c}2.29 * * \\
(2.95 * * *)\end{array}$ \\
\hline Leverage $_{\text {ind Ajdusted }}$ & $\begin{array}{c}0.01 \\
(0.02)\end{array}$ & $\begin{array}{c}0.02 \\
(0.03)\end{array}$ & $\begin{array}{c}0.01 \\
(-0.00)\end{array}$ & $\begin{array}{l}-0.01 \\
(0.01)\end{array}$ & $\begin{array}{c}3.08^{* * *} \\
\left(3.78^{* * *}\right)\end{array}$ \\
\hline Firm Size $_{\text {ind Ajdusted }}$ & $\begin{array}{c}-1.20 \\
(-1.23)\end{array}$ & $\begin{array}{c}-1.41 \\
(-1.53)\end{array}$ & $\begin{array}{l}-1.30 \\
(-1.26)\end{array}$ & $\begin{array}{l}-0.89 \\
(-1.02)\end{array}$ & $\begin{array}{l}3.89 * * * \\
(2.17 * *)\end{array}$ \\
\hline$H H I$ & $\begin{array}{c}0.076 \\
(0.042)\end{array}$ & $\begin{array}{c}0.060 \\
(0.032)\end{array}$ & $\begin{array}{c}0.076 \\
(0.045)\end{array}$ & $\begin{array}{c}0.092 \\
(0.065)\end{array}$ & $\begin{array}{c}1.60 \\
(1.25)\end{array}$ \\
\hline Pre 1 Month IPOs & $\begin{array}{c}21.41 \\
(24.00)\end{array}$ & $\begin{array}{c}25.74 \\
(28.00)\end{array}$ & $\begin{array}{c}22.96 \\
(22.00)\end{array}$ & $\begin{array}{c}15.58 \\
(13.00)\end{array}$ & $\begin{array}{c}11.84^{* * *} \\
\left(10.09^{* * *}\right)\end{array}$ \\
\hline Small and Median Board & 0.69 & 0.70 & 0.63 & 0.73 & 0.65 \\
\hline
\end{tabular}




\begin{tabular}{cccccc} 
& $(1.00)$ & $(1.00)$ & $(1.00)$ & $(1.00)$ & $(0.64)$ \\
Growth Enterprise Board & 0.21 & 0.25 & 0.26 & 0.11 & $4.02^{* * *}$ \\
& $(0.00)$ & $(0.00)$ & $(0.00)$ & $(0.00)$ & $\left(3.96^{* * *}\right)$ \\
\hline
\end{tabular}




\section{Table 3. Model of Mutual Funds Selection of IPO Firms}

This table formulates a model of mutual funds selection of IPO firms during the period 2005-2010. The dependent variable is Original Funds, measured as the number of mutual funds that buy new firms in IPO primary market. The independent variables includes: Reputable Underwriter , a dummy variable equals one when the total amounts of IPO shares sold or the total number of IPO firms it underwrote is at top $10 \%$ during the last three years, and zero otherwise; Big4, a dummy variable equals one when the auditor is one of the big 4 international accounting firms which includes PWC, Ernst \& Young, DTT, KPMG, and zero otherwise; IPO underpricing, measured as the difference between the closing price on the first trading day and the offering price, divided by the offering price; IPO value, measured as the natural logarithm of the offering size; P/E Ratio, measured as the ratio of the offering price to earnings per share (EPS), where EPS is the ratio of the average annual earnings during three years before the IPO to the total number of post-offering shares; Offer Price, measured as the offer price for IPO firm; Offer Ratio, measured as the ratio of the new shares offered in the primary market to the total shares; Largest ownership, measured as the percentage ownership of the largest owner; Pyramid, a dummy that equals one if the ultimate owner controls the listed firm through at least one firm, and zero otherwise; Non-Duality, a dummy which equals one if the CEO is not the Chair of Board, and zero otherwise; Independent Directors, measured as the ratio of independent directors on the board; Other Institutions, the ratio of other institutional shareholders' aggregate holdings over total shares, where such institutions refer to VC/PE firms, pension funds, trust funds, insurance companies, and assets management products from brokerage houses; Private Firm, a dummy variable equals one when its ultimate owner is a person or its family, and zero otherwise; Industry Leader, an indicator for whether the firm is an industry leader, measured as whether the sales of IPO firm ranked as top 30\% in its industry; Sales Growth, measured as the average ratio of growth rate of sales for IPO firms during the three years before IPO; ROE, measured as the average ratio of return on equities for IPO firms during the three years before IPO; Leverage, measured as the average ratio of total long-term and short-term debt to total assets for IPO firms during the three years before IPO; Firm Size, measured as the average value of the natural logarithm of total assets for IPO firms during the three years before IPO. Sales Growth, ROE, and Leverage and Firm Size are all further adjusted by industry according to CSRC industry standards. HHI (Herfindahl-Hirschman Index), an indicator of competition, estimated using all listed firms' sales from the same industry just before the IPO; Pre 1 Month IPOs, measured as the number of New IPOs during the last month. Listing Board (Small and Median Board, Growth Enterprise Board), year and industry dummies are also included but not reported. We use the Model IV as the final model to predict the determinants of mutual funds selection of IPO firms and use the residuals from this model in all our subsequent analysis. T-statistics based on standard errors clustered by year and industry are given in parentheses. All continuous variables are winsorized at the top and bottom $1 \%$. ${ }^{* * *}, * *$, and $*$ denote significance at the $1 \%, 5 \%$ and $10 \%$ level, respectively. 


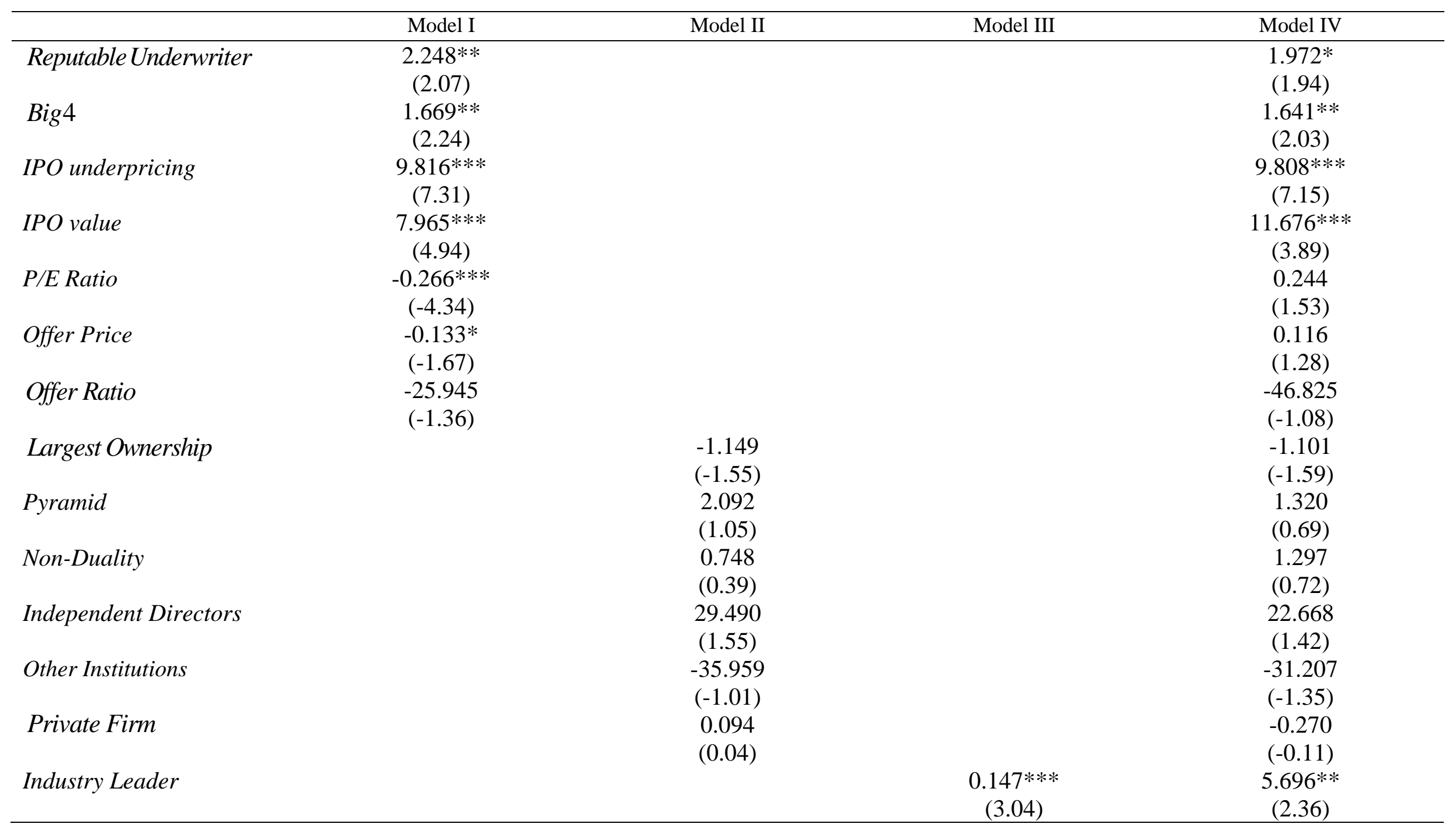




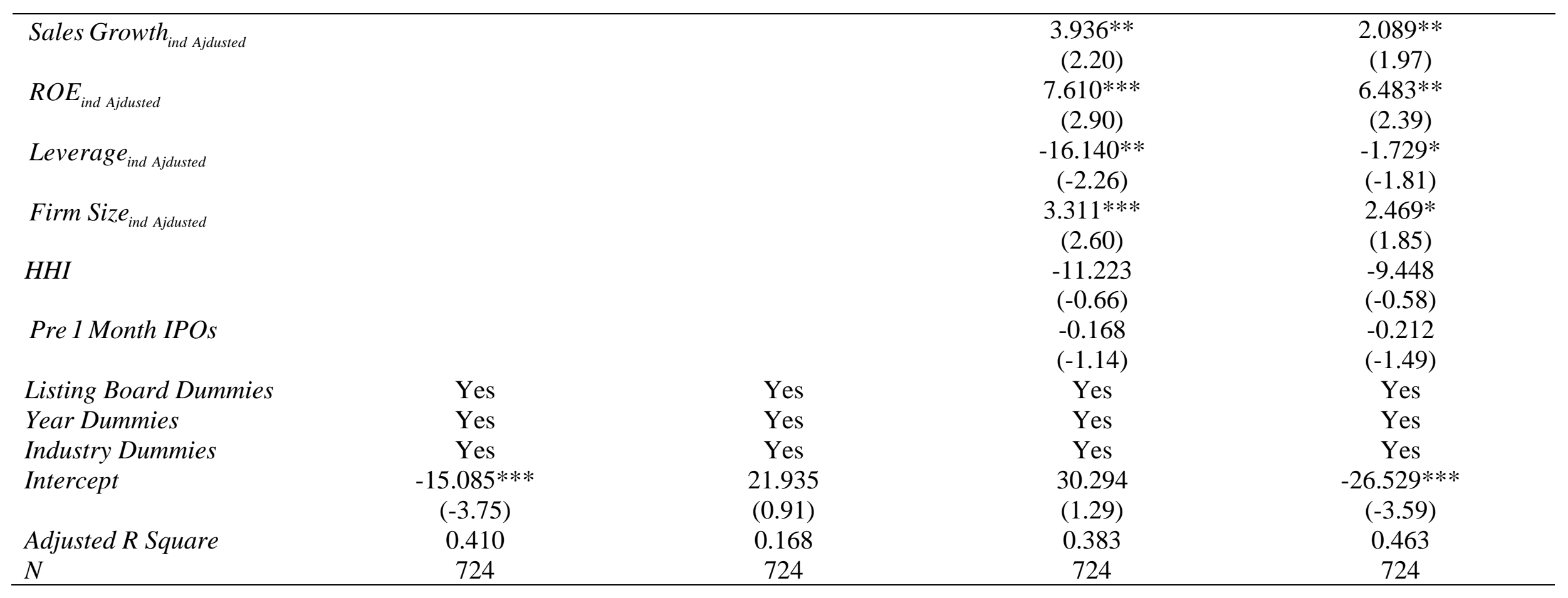




\section{Table 4. 1- and 3-Year Buy-and-Hold Abnormal Returns after IPOs}

The sample of IPOs is identified in Table 1. Subsamples of IPO firms with low, medium, and high residual funds consist of firms with below the 33.33, between the 33.33 and 66.67, and above the 66.67 percentile residual funds, which is the residual from the model of Original Funds on Reputable Underwriter, Big4, IPO underpricing, IPO value, P/E Ratio, Offer Price, Offer Ratio Largest ownership, Pyramid, Non-Duality, Independent Directors, Other Institutions, Private Firm, Industry Leader, industry-adjusted sales growth, industry-adjusted ROE, industryadjusted leverage, industry-adjusted firm size, HHI, Pre 1 Month IPOs and Listing Board/Year/Industry Dummies (Model IV in Table 3). The period used to calculate the returns is measured from the $6^{\text {th }}$ to $257^{\text {th }}$ trading days (1-year) and the $6^{\text {th }}$ to $760^{\text {th }}$ trading days (3-year) subsequent to the IPO issuance. Panel A and B report the 1- and 3- year buy-and-hold abnormal returns (BHARs), respectively. The BHARs are alternatively benchmarked against an equally weighted all A stock shares index (in row a.1 and b.1), a tradable value weighted all A stock shares index (in row a.2 and b.2), or Size and B/M matching portfolios (in row a.3 and b.3). The mean of the BHARs are reported (with the corresponding median values in parentheses). The last column reports a $T$-test (Wilcoxon-Mann-Whitney test in parentheses) of the difference between High and Low residual mutual fund investment portfolios. ***, **, and * denote significance at the $1 \%, 5 \%$ and $10 \%$ level, respectively. 


\begin{tabular}{|c|c|c|c|c|c|}
\hline & $\begin{array}{c}\text { Full } \\
\text { Sample } \\
(1)\end{array}$ & $\begin{array}{c}\text { Low } \\
\text { Residual Funds } \\
\text { (2) }\end{array}$ & $\begin{array}{c}\text { Median } \\
\text { Residual Funds } \\
\text { (3) }\end{array}$ & $\begin{array}{c}\text { High } \\
\text { Residual Funds } \\
\text { (4) }\end{array}$ & $\begin{array}{c}\text { T-Test } \\
\text { (WMW-Test) } \\
(4)-(2)\end{array}$ \\
\hline \multicolumn{6}{|c|}{ Panel A: 1-Year Buy-and-Hold Abnormal Returns after IPOs } \\
\hline (a.1) Return in Excess of Equally & $-0.381 * * *$ & $-0.516 * * *$ & $-0.357 * * *$ & $-0.195 * * *$ & $6.97 * * *$ \\
\hline Weighted all A Stock Shares Index & $(-0.273)$ & $(-0.364)$ & $(-0.291)$ & $(-0.174)$ & $(5.38 * * *)$ \\
\hline (a.2) Return in Excess of Tradable & $-0.152 * * *$ & $-0.264 * * *$ & $-0.162 * * *$ & -0.007 & $5.97 * * *$ \\
\hline Value Weighted All A Stock Shares & $(-0.126)$ & $(-0.229)$ & $(-0.101)$ & $(-0.012)$ & $\left(8.16^{* * *}\right)$ \\
\hline Index & & & & & \\
\hline (a.3) Return in Excess of Size and & $-0.079 * * *$ & $-0.114 *$ & $-0.068 * * *$ & $-0.021 * *$ & $4.63 * * *$ \\
\hline B/M Matching Portfolios & $(-0.046)$ & $(-0.119)$ & $(-0.045)$ & $(-0.017)$ & $(3.91 * * *)$ \\
\hline \multicolumn{6}{|c|}{ Panel B: 3-Year Buy-and-Hold Abnormal Returns after IPOs } \\
\hline (b.1) Return in Excess of Equally & $-0.681 * * *$ & $-0.728 * * *$ & $-0.646^{* * *}$ & $-0.524 * * *$ & $3.75 * * *$ \\
\hline Weighted All A Stock Shares Index & $(-0.734)$ & $(-0.542)$ & $(-0.422)$ & $(-0.406)$ & $(5.96 * * *)$ \\
\hline (b.2) Return in Excess of Tradable & 0.006 & $-0.157 * * *$ & -0.019 & $0.141 * *$ & $3.91 * * *$ \\
\hline $\begin{array}{l}\text { Value Weighted All A Stock Shares } \\
\text { Index }\end{array}$ & $(0.004)$ & $(-0.213)$ & $(-0.128)$ & $(0.083)$ & $(5.27 * * *)$ \\
\hline (b.3) Return in Excess of Size and & $-0.052 * * *$ & $-0.194 * * *$ & $-0.085 *$ & $0.127 * *$ & $5.60 * * *$ \\
\hline B/M Matching Portfolios & $(-0.047)$ & $(-0.096)$ & $(-0.073)$ & $(0.079)$ & $(4.82 * * *)$ \\
\hline
\end{tabular}


Table 5. Carhart's Four Factor Model

The IPO sample is presented in Table 1. Subsamples of IPO firms with low, medium, and high residual funds consist of firms with below 33.33, between 33.33 and 66.67, and above 66.67 percentile residual funds, respectively. Residual funds is the residual from the model of Original Funds on Reputable Underwriter, Big4, IPO underpricing, IPO value, P/E Ratio, Offer Price, Offer Ratio Largest ownership, Pyramid, Non-Duality, Independent Directors, Other Institutions, Private Firm, Industry Leader, industry-adjusted sales growth, industry-adjusted ROE, industry-adjusted leverage, industry-adjusted firm size, HHI, Pre 1 Month IPOs and Listing Board/Year/Industry Dummies (Model IV in Table 3). Returns are measured from the $6^{\text {th }}$ to the $257^{\text {th }}$ trading day (1-year regression model) and from the $6^{\text {th }}$ to the $760^{\text {th }}$ trading day (3year regression model) subsequent to the IPO. $R_{p, t}$ is the equally weighted returns of the IPO portfolio in calendar month $t$. $R_{m, t}$ is the return on the tradable value weighted index of all Ashares in month $t$. $R_{f, t}$ is the risk-free interest rate, calculated based on the 3-month deposit rate set by People's Bank of China. $S M B_{t}$ is the return on small firms minus the return on large firms in month t. $H M L_{t}$ is the return on high book-to-market stocks minus the return on low book-tomarket stocks in month $t$ (Fama and French 1992, 1993). $U M D_{t}$ is the return on high momentum stocks minus the return on low momentum stocks in month $t$ (Carhart, 1997). Panel A and B report the 1-year and 3-year regression results of portfolios of low, medium and high residual funds, respectively. In the final row of each panel, we report the results of a zero-investment portfolio, which is created by buying high and shorting low residual funds and rebalanced monthly. Coefficients are given in the table with corresponding $t$-statistics in parentheses. ***, $* *$, and $*$ denote significance at the $1 \%, 5 \%$ and $10 \%$ level, respectively.

\begin{tabular}{|c|c|c|c|c|c|c|}
\hline & $a$ & $b$ & $S$ & $h$ & $m$ & $\begin{array}{c}\text { Adjusted } \\
R^{2}\end{array}$ \\
\hline \multicolumn{7}{|c|}{ Panel A: 1-Year Four-Factor Regression Model } \\
\hline Low Residual Funds & $\begin{array}{c}-0.026 * * * \\
(-3.25)\end{array}$ & $\begin{array}{c}0.827 * * * \\
(10.13)\end{array}$ & $\begin{array}{c}0.714^{* * * *} \\
(6.85)\end{array}$ & $\begin{array}{c}-0.135 * * \\
(-2.02)\end{array}$ & $\begin{array}{l}-0.009 \\
(-0.86)\end{array}$ & 0.782 \\
\hline Medium Residual Funds & $\begin{array}{c}-0.008 * * \\
(-2.34)\end{array}$ & $\begin{array}{c}0.905^{* * *} \\
(12.37)\end{array}$ & $\begin{array}{c}0.642 * * * \\
(4.06)\end{array}$ & $\begin{array}{c}-0.443^{*} \\
(-1.82)\end{array}$ & $\begin{array}{l}-0.024 \\
(-1.07)\end{array}$ & 0.771 \\
\hline High Residual Funds & $\begin{array}{c}0.002 * * \\
(2.28)\end{array}$ & $\begin{array}{c}0.942 * * * \\
(16.47)\end{array}$ & $\begin{array}{c}0.283^{* *} \\
(2.85)\end{array}$ & $\begin{array}{c}-0.770 * * * \\
(-4.21)\end{array}$ & $\begin{array}{l}-0.023^{*} \\
(-1.77)\end{array}$ & 0.735 \\
\hline $\begin{array}{l}\text { Zero-investment } \\
\text { Portfolios }\end{array}$ & $\begin{array}{c}0.028 * * * \\
(4.61)\end{array}$ & $\begin{array}{l}0.015 \\
(0.74)\end{array}$ & $\begin{array}{c}-0.411^{* * *} \\
(-3.95)\end{array}$ & $\begin{array}{c}-0.634^{* * *} \\
(-2.68)\end{array}$ & $\begin{array}{l}-0.014 \\
(-1.07)\end{array}$ & 0.281 \\
\hline \multicolumn{7}{|c|}{ Panel B: 3-Year Four-Factor Regression Model } \\
\hline Low Residual Funds & $\begin{array}{l}-0.004^{* * *} \\
(-4.76)\end{array}$ & $\begin{array}{l}0.753 * * * \\
(24.81)\end{array}$ & $\begin{array}{l}0.728 * * * \\
(8.83)\end{array}$ & $\begin{array}{l}-0.168 * * * \\
(-5.60)\end{array}$ & $\begin{array}{l}-0.035 \\
(-1.29)\end{array}$ & 0.819 \\
\hline Medium Residual Funds & $\begin{array}{l}0.002 \\
(0.53)\end{array}$ & $\begin{array}{l}0.904 * * * \\
(18.43)\end{array}$ & $\begin{array}{l}0.605 * * * \\
(9.76)\end{array}$ & $\begin{array}{l}-0.427 * * * \\
(-6.63)\end{array}$ & $\begin{array}{l}-0.027 \\
(-1.01)\end{array}$ & 0.804 \\
\hline High Residual Funds & $\begin{array}{l}0.005 * * * \\
(2.78)\end{array}$ & $\begin{array}{l}0.911 * * * \\
(20.17)\end{array}$ & $\begin{array}{l}0.336 * * * \\
(8.85)\end{array}$ & $\begin{array}{l}-0.435 * * * \\
(-6.13)\end{array}$ & $\begin{array}{l}-0.018 * * \\
(-2.07)\end{array}$ & 0.847 \\
\hline $\begin{array}{l}\text { Zero-investment } \\
\text { Portfolios }\end{array}$ & $\begin{array}{l}0.009 * * * \\
(6.73)\end{array}$ & $\begin{array}{l}0.158^{* *} \\
(2.39)\end{array}$ & $\begin{array}{l}-0.392 * * \\
(-2.18)\end{array}$ & $\begin{array}{l}-0.267 * * * * \\
(-4.12)\end{array}$ & $\begin{array}{l}-0.010 \\
(-1.09)\end{array}$ & 0.313 \\
\hline
\end{tabular}




\section{Table 6. Fama-MacBeth's Cross-Sectional Regression Model}

The total sample includes all A-share stocks on the Shanghai and Shenzhen stock exchanges. $M V$ is the market capitalization at the end of the previous year. $B V / M V$ is the ratio of the book value of equity to the market value of equity at the end of the previous year. Issue is a dummy variable that equals if the firm conducted one or more public equity issues within the previous year in Model I (and within the previous three years in Model II) and zero otherwise. Residual funds is the residual from the model of Original Funds on Reputable Underwriter, Big4, IPO underpricing, IPO value, P/E Ratio, Offer Price, Offer Ratio Largest ownership, Pyramid, NonDuality, Independent Directors, Other Institutions, Private Firm, Industry Leader, industryadjusted sales growth, industry-adjusted ROE, industry-adjusted leverage, industry-adjusted firm size, HHI, Pre 1 Month IPOs and Listing Board/Year/Industry Dummies (Model IV in Table 3). Reputable Underwriter is a dummy variable equals one when the total amounts of IPO shares sold or the total number of IPO firms it underwrote is at top $10 \%$ during the last three years, and zero otherwise. Big4 is a dummy variable that equals one when the auditor is one of the big 4 international accounting firms (Deloitte, Ernst \& Young, KPMG, and PricewaterhouseCoopers) and zero otherwise. The average parameter values are given with $t$ statistics in parentheses. ${ }^{* * *}, * *$, and $*$ denote significance at the $1 \%, 5 \%$ and $10 \%$ level, respectively.

\begin{tabular}{lcc}
\hline & Model I & Model II \\
& $(1-$ Year) & $(3-$ Year) \\
\hline Log(MV) & $-0.031^{* * *}$ & $-0.062^{* * *}$ \\
& $(-17.73)$ & $(-12.09)$ \\
Log(BV/MV) & $-0.018^{* * *}$ & $-0.041^{*}$ \\
Issue & $(-4.25)$ & $(-1.92)$ \\
& $-0.013^{*}$ & $-0.024^{*}$ \\
Residual Funds* Issue & $(-1.81)$ & $(-1.75)$ \\
& $0.006^{* * *}$ & $0.013^{* *}$ \\
Reputable Underwriter* Issue & $(3.18)$ & $(2.43)$ \\
& $0.015^{* * *}$ & $0.007^{* *}$ \\
Big4* Issue & $(3.49)$ & $(2.10)$ \\
& 0.031 & $0.026^{* *}$ \\
Intercept & $(1.46)$ & $(2.19)$ \\
& $-0.114^{* * *}$ & $-0.206^{* * *}$ \\
Average $R^{2}$ & $(-24.80)$ & $(-19.67)$ \\
Number of Months & 0.153 & 0.126 \\
\end{tabular}


Table 7. Operating Performance of IPO Portfolios Sorted by Residual Funds

The sample of IPOs is presented in Table 1. Subsamples of IPO firms with low, medium, and high residual funds consist of firms with below the 33.33, between the 33.33 and 66.67, and above the 66.67 percentile of residual funds, respectively. Residual funds is the residual from the model of Original Funds on Reputable Underwriter, Big4, IPO underpricing, IPO value, P/E Ratio, Offer Price, Offer Ratio Largest ownership, Pyramid, Non-Duality, Independent Directors, Other Institutions, Private Firm, Industry Leader, industry-adjusted sales growth, industry-adjusted ROE, industry-adjusted leverage, industry-adjusted firm size, HHI, Pre 1 Month IPOs and Listing Board/Year/Industry Dummies (Model IV in Table 3). ROA is the return on assets, measured as net income over total assets; ROS is the return on sales, measured as net income over total sales; and ROE is the return on equity, measured as net income over shareholder's equity. On the right-hand-side of the table, ROA, ROS and ROE are all adjusted by industry as identified by CSRC. Mean values are reported with the corresponding median values in parentheses. T-tests and Wilcoxon-Mann-Whitney tests are provided for the mean and median comparison of Low Residual Funds sample and High Residual Funds sample. ***, **, and * denote significance at the $1 \%, 5 \%$ and $10 \%$ level, respectively.

\begin{tabular}{|c|c|c|c|c|c|c|}
\hline & \multicolumn{3}{|c|}{$\mathrm{ROA}$} & \multicolumn{3}{|c|}{ Industry-Adjusted ROA } \\
\hline & Year 1 & Year 2 & Year 3 & Year 1 & Year 2 & Year 3 \\
\hline Low & 0.060 & 0.053 & 0.046 & -0.059 & -0.071 & -0.010 \\
\hline $\begin{array}{l}\text { Residual } \\
\text { Funds }\end{array}$ & $(0.067)$ & $(0.046)$ & $(0.037)$ & $(-0.001)$ & $(-0.009)$ & $(-0.006)$ \\
\hline $\begin{array}{l}\text { Medium } \\
\text { Residual } \\
\text { Funds }\end{array}$ & $\begin{array}{c}0.073 \\
(0.079)\end{array}$ & $\begin{array}{c}0.061 \\
(0.055)\end{array}$ & $\begin{array}{c}0.048 \\
(0.050)\end{array}$ & $\begin{array}{c}0.006 \\
(0.002)\end{array}$ & $\begin{array}{c}0.002 \\
(0.004)\end{array}$ & $\begin{array}{c}0.018 \\
(0.011)\end{array}$ \\
\hline $\begin{array}{l}\text { High } \\
\text { Residual } \\
\text { Funds }\end{array}$ & $\begin{array}{c}0.081 \\
(0.097)\end{array}$ & $\begin{array}{c}0.072 \\
(0.076)\end{array}$ & $\begin{array}{c}0.064 \\
(0.071)\end{array}$ & $\begin{array}{c}0.017 \\
(0.026)\end{array}$ & $\begin{array}{c}0.016 \\
(0.021)\end{array}$ & $\begin{array}{c}0.021 \\
(0.024)\end{array}$ \\
\hline $\begin{array}{l}\text { T-Test } \\
\text { (WMW- } \\
\text { Test) }\end{array}$ & $\begin{array}{c}2.38^{* *} \\
(4.74 * * *)\end{array}$ & $\begin{array}{c}4.27 * * * \\
\left(5.83^{* * *}\right)\end{array}$ & $\begin{array}{c}2.16^{* *} \\
\left(3.83^{* *}\right)\end{array}$ & $\begin{array}{l}4.54 * * * \\
\left(4.65^{* * *}\right)\end{array}$ & $\begin{array}{l}4.95^{* * * *} \\
\left(6.05^{* * *}\right)\end{array}$ & $\begin{array}{l}5.86 * * * \\
(3.69 * * *)\end{array}$ \\
\hline & \multicolumn{3}{|c|}{ ROS } & \multicolumn{3}{|c|}{ Industry-Adjusted ROS } \\
\hline $\begin{array}{l}\text { Low } \\
\text { Residual } \\
\text { Funds }\end{array}$ & $\begin{array}{c}0.121 \\
(0.126)\end{array}$ & $\begin{array}{c}0.080 \\
(0.073)\end{array}$ & $\begin{array}{c}0.067 \\
(0.066)\end{array}$ & $\begin{array}{c}-0.041 \\
(0.015)\end{array}$ & $\begin{array}{l}-0.085 \\
(0.024)\end{array}$ & $\begin{array}{c}-0.035 \\
(-0.005)\end{array}$ \\
\hline $\begin{array}{l}\text { Medium } \\
\text { Residual } \\
\text { Funds }\end{array}$ & $\begin{array}{c}0.159 \\
(0.145)\end{array}$ & $\begin{array}{c}0.116 \\
(0.105)\end{array}$ & $\begin{array}{c}0.093 \\
(0.083)\end{array}$ & $\begin{array}{c}0.032 \\
(0.043)\end{array}$ & $\begin{array}{c}0.020 \\
(0.009)\end{array}$ & $\begin{array}{c}0.013 \\
(0.006)\end{array}$ \\
\hline $\begin{array}{l}\text { High } \\
\text { Residual } \\
\text { Funds }\end{array}$ & $\begin{array}{c}0.182 \\
(0.192)\end{array}$ & $\begin{array}{c}0.162 \\
(0.143)\end{array}$ & $\begin{array}{c}0.148 \\
(0.132)\end{array}$ & $\begin{array}{c}0.061 \\
(0.079)\end{array}$ & $\begin{array}{c}0.046 \\
(0.064)\end{array}$ & $\begin{array}{c}0.037 \\
(0.029)\end{array}$ \\
\hline $\begin{array}{l}T \text {-Test } \\
\text { (WMW- } \\
\text { Test) }\end{array}$ & $\begin{array}{c}1.79 * \\
(4.45 * * *)\end{array}$ & $\begin{array}{c}2.25^{* *} \\
\left(3.36^{* * *}\right)\end{array}$ & $\begin{array}{c}6.71^{* * *} \\
\left(8.14^{* * *}\right)\end{array}$ & $\begin{array}{c}9.71 * * * \\
(5.46 * * *)\end{array}$ & $\begin{array}{c}3.14 * * * \\
(4.28 * * *)\end{array}$ & $\begin{array}{l}4.63^{* *} \\
\left(1.92^{*}\right)\end{array}$ \\
\hline & \multicolumn{3}{|c|}{$\mathrm{ROE}$} & \multicolumn{3}{|c|}{ Industry-Adjusted ROE } \\
\hline Low & 0.083 & 0.065 & 0.064 & 0.017 & 0.024 & 0.016 \\
\hline
\end{tabular}




\begin{tabular}{|c|c|c|c|c|c|c|}
\hline $\begin{array}{l}\text { Residual } \\
\text { Funds }\end{array}$ & $(0.069)$ & $(0.089)$ & $(0.092)$ & $(0.025)$ & $(0.031)$ & $\begin{array}{l}(0.023) \\
\end{array}$ \\
\hline $\begin{array}{l}\text { Medium } \\
\text { Residual } \\
\text { Funds }\end{array}$ & $\begin{array}{c}0.095 \\
(0.091)\end{array}$ & $\begin{array}{c}0.114 \\
(0.105)\end{array}$ & $\begin{array}{c}0.105 \\
(0.127)\end{array}$ & $\begin{array}{c}0.041 \\
(0.038)\end{array}$ & $\begin{array}{c}0.037 \\
(0.030)\end{array}$ & $\begin{array}{c}0.032 \\
(0.039)\end{array}$ \\
\hline $\begin{array}{l}\text { High } \\
\text { Residual } \\
\text { Funds }\end{array}$ & $\begin{array}{c}0.132 \\
(0.118)\end{array}$ & $\begin{array}{c}0.141 \\
(0.124)\end{array}$ & $\begin{array}{c}0.142 \\
(0.136)\end{array}$ & $\begin{array}{c}0.051 \\
(0.052)\end{array}$ & $\begin{array}{c}0.049 \\
(0.038)\end{array}$ & $\begin{array}{c}0.043 \\
(0.034)\end{array}$ \\
\hline $\begin{array}{l}T \text {-Test } \\
\text { (WMW- } \\
\text { Test) }\end{array}$ & $\begin{array}{c}2.18^{* *} \\
\left(2.04^{* *}\right)\end{array}$ & $\begin{array}{c}4.67 * * * \\
\left(6.75^{* * *}\right)\end{array}$ & $\begin{array}{c}4.95^{* *} \\
\left(5.33^{* * *}\right)\end{array}$ & $\begin{array}{c}4.64 * * * \\
(1.72 *)\end{array}$ & $\begin{array}{c}2.29 * * \\
(1.13)\end{array}$ & $\begin{array}{l}4.26^{* * *} \\
\left(3.97^{* *}\right)\end{array}$ \\
\hline
\end{tabular}


Table 8. 3-Year Buy-and-Hold Abnormal Returns after IPOs by Corporate Governance Characteristics and Residual Funds

This table presents the 3-year buy-and-hold abnormal returns (BHARs) that are benchmarked against the Size and B/M matching portfolios. The sample of IPOs is identified in Table 1. Subsamples of IPO firms with low, medium, and high residual mutual funds consist of firms characterized by below 33.3, between 33.3 and 66.7, and above 66.7 percentile residual funds. Residual funds is the residual from the model of Original Funds on Reputable Underwriter, Big4, IPO underpricing, IPO value, P/E Ratio, Offer Price, Offer Ratio Largest ownership, Pyramid, Non-Duality, Independent Directors, Other Institutions, Private Firm, Industry Leader, industry-adjusted sales growth, industry-adjusted ROE, industry-adjusted leverage, industryadjusted firm size, HHI, Pre 1 Month IPOs and Listing Board/Year/Industry Dummies (Model IV in Table 3). Pyramid is a dummy that equals one if the ultimate owner controls the listed firm through at least one firm, and zero otherwise. Non-Duality is a dummy which equals one if the CEO is not the Chair of Board, and zero otherwise. Independent Directors is the ratio of independent directors on the board. Other Institutions is the ratio of other institutional shareholders' aggregate holdings over total shares, where such institutions refer to VC/PE firms, pension funds, trust funds, insurance companies, and assets management products from brokerage houses. Largest Ownership is the percentage ownership in the company held by the largest owner. Private Firm is a dummy that equals one if the ultimate owner is a person, and zero otherwise. In panel A, B and F, portfolios are alternatively formed based on whether Pyramid, Non-Duality, and Private Firm is equal to one, and then sorted into tertiles of residual funds independently. In panel C, D and E, portfolios are alternatively formed based on whether Independent Directors, Other Institutions, and Largest Ownership are above their corresponding median value, and then sorted into tertiles of residual funds independently. The mean of the 3year BHARs are reported (with the corresponding median values in parentheses). The final column reports a T-test (Wilcoxon-Mann-Whitney test in parentheses) of the difference between High and Low residual funds portfolios. The last row (a)-(b) in each panel reports a T-test (Wilcoxon-Mann-Whitney test in parentheses) of the difference between portfolios with Low and High corporate governance. ${ }^{* * *}, * *$, and $*$ denote significance at the $1 \%, 5 \%$ and $10 \%$ level, respectively.

\begin{tabular}{lcccc}
\hline & $\begin{array}{c}\text { Low } \\
\text { Residual } \\
\text { Funds } \\
(1)\end{array}$ & $\begin{array}{c}\text { Median } \\
\text { Residual } \\
\text { Funds } \\
(2)\end{array}$ & $\begin{array}{c}\text { High } \\
\text { Residual } \\
\text { Funds } \\
(3)\end{array}$ & $\begin{array}{c}\text { T-Test } \\
\text { (WMW-Test) }\end{array}$ \\
\hline Panel A: Pyramid & & & & \\
\hline (a) 1 & -0.223 & 0.037 & 0.093 & $3.94^{* * *}$ \\
& $(-0.196)$ & $(0.046)$ & $(0.125)$ & $\left(5.96^{* * *}\right)$ \\
(b) 0 & -0.156 & 0.058 & 0.142 & $4.87^{* * *}$ \\
& $(-0.175)$ & $(0.043)$ & $(0.164)$ & $\left(3.72^{* * *}\right)$ \\
Test of Difference & 0.51 & 1.06 & 0.79 & \\
(a)-(b) & $(0.48)$ & $(0.52)$ & $(0.83)$ & \\
\hline
\end{tabular}


Panel B: Non-Duality

\begin{tabular}{lcccc} 
(a) 1 & -0.253 & -0.063 & 0.102 & $3.95^{* * *}$ \\
& $(-0.154)$ & $(-0.087)$ & $(0.093)$ & $\left(4.68^{* * *}\right)$ \\
(b) 0 & -0.137 & -0.027 & 0.134 & $4.82^{* * *}$ \\
& $(-0.182)$ & $(-0.036)$ & $(0.121)$ & $\left(3.70^{* * *}\right)$ \\
Test of Difference & 1.24 & 0.49 & 0.47 & \\
(a)-(b) & $(0.71)$ & $(0.25)$ & $(0.53)$ & \\
\hline
\end{tabular}

Panel C: Independent Directors

\begin{tabular}{lcccc}
\hline (a) Low & -0.175 & -0.025 & 0.152 & $5.47^{* * *}$ \\
& $(-0.134)$ & $(-0.037)$ & $(0.138)$ & $\left(4.83^{* * *}\right)$ \\
(b) High & -0.218 & -0.062 & 0.098 & $2.20^{* *}$ \\
& $(-0.235)$ & $(-0.076)$ & $(0.106)$ & $\left(3.95^{* *}\right)$ \\
Test of Difference & 0.27 & 0.96 & 0.83 & \\
(a)-(b) & $(0.81)$ & $(0.37)$ & $(0.42)$ & \\
\hline
\end{tabular}

Panel D: Other Institutions

\begin{tabular}{lcccc}
\hline (a) Low & -0.158 & -0.067 & 0.135 & $5.95^{* * *}$ \\
& $(-0.197)$ & $(0.082)$ & $(0.126)$ & $\left(4.83^{* * * *}\right)$ \\
(b) High & -0.241 & -0.101 & 0.114 & $3.47^{* * *}$ \\
& $(-0.280)$ & $(-0.097)$ & $(0.149)$ & $(2.39 * *)$ \\
Test of Difference & 0.86 & 1.29 & 0.83 & \\
(a)-(b) & $(0.57)$ & $(1.14)$ & $(1.46)$ & \\
\hline
\end{tabular}

Panel E: Largest Ownership

\begin{tabular}{lcccc}
\hline (a) Low & -0.203 & -0.096 & 0.106 & $5.63^{* * *}$ \\
& $(-0.217)$ & $(-0.113)$ & $(0.130)$ & $\left(4.95^{* * *}\right)$ \\
(b) High & -0.176 & -0.075 & 0.148 & $3.32^{* * *}$ \\
& $(-0.191)$ & $(-0.094)$ & $(0.162)$ & $\left(4.17^{* * *}\right)$ \\
Test of Difference & 0.46 & 1.31 & 1.08 & \\
(a)-(b) & $(1.46)$ & $(0.09)$ & $(0.81)$ & \\
\hline
\end{tabular}

Panel F: Private firm

\begin{tabular}{lcccc}
\hline (a) 1 & -0.182 & 0.097 & 0.147 & $4.52^{* * *}$ \\
& $(-0.163)$ & $(0.075)$ & $(0.124)$ & $\left(3.80^{* * *}\right)$ \\
(b) 0 & -0.217 & 0.069 & 0.104 & $3.16^{* * *}$ \\
& $(-0.249)$ & $(0.043)$ & $(0.050)$ & $\left(1.95^{*}\right)$ \\
Test of Difference & 1.26 & 0.35 & 0.87 & \\
(a)-(b) & $(1.04)$ & $(0.57)$ & $(1.34)$ & \\
\hline
\end{tabular}


Table 9. Disentangling the Stock Selection Effect from the Monitoring Effect

This table presents the results from the empirical analysis in which the stock selection effect is disentangled from the monitoring effect of mutual funds. The sample of IPOs is identified in Table 1. Subsamples of IPO firms with low, medium, and high residual funds consist of firms characterized by below 33.3, between 33.3 and 66.7, and above 66.7 percentile residual funds. Residual funds is the residual from the model of Original Funds on Reputable Underwriter, Big4, IPO underpricing, IPO value, P/E Ratio, Offer Price, Offer Ratio Largest ownership, Pyramid, Non-Duality, Independent Directors, Other Institutions, Private Firm, Industry Leader, industry-adjusted sales growth, industry-adjusted ROE, industry-adjusted leverage, industryadjusted firm size, HHI, Pre 1 Month IPOs and Listing Board/Year/Industry Dummies (Model IV in Table 3). Fund turnover is measured as the total amount of purchase and sale transactions over its stock holdings. Sell ratio after one year (three years), measured as the number of mutual funds that heavily sell off the IPO stock within one year (three years) after the IPO, divided by the total number of funds that purchase it in the primary market. The mean values are reported, with the corresponding median values in parentheses. The final column reports a T-test (Wilcoxon-Mann-Whitney test in parentheses) of the difference between High and Low residual funds. ${ }^{* * *},{ }^{* *}$, and ${ }^{*}$ denote significance at the $1 \%, 5 \%$ and $10 \%$ level, respectively.

\begin{tabular}{lcccc}
\hline & $\begin{array}{c}\text { Low } \\
\text { Residual } \\
\text { Funds } \\
(1)\end{array}$ & $\begin{array}{c}\text { Median } \\
\text { Residual } \\
\text { Funds } \\
(2)\end{array}$ & $\begin{array}{c}\text { High } \\
\text { Residual } \\
\text { Funds } \\
(3)\end{array}$ & $\begin{array}{c}\text { T-Test } \\
\text { (WMW-Test) }\end{array}$ \\
\hline Fund turnover & $228.35 \%$ & $321.81 \%$ & $487.90 \%$ & $6.26^{* * *}$ \\
& $(187.54 \%)$ & $(301.09 \%)$ & $(478.74 \%)$ & $\left(4.85^{* * *}\right)$ \\
$\begin{array}{l}\text { Sell ratio } \\
\text { after one year }\end{array}$ & $44.09 \%$ & $58.30 \%$ & $69.87 \%$ & 1.42 \\
& $(31.76 \%)$ & $(51.89 \%)$ & $(72.36 \%)$ & $\left(2.39^{* *}\right)$ \\
$\begin{array}{l}\text { Sell ratio } \\
\text { after three years }\end{array}$ & $75.64 \%$ & $90.79 \%$ & $95.19 \%$ & $1.75^{*}$ \\
\hline
\end{tabular}

